\title{
New alternatives for improving and assessing the color of dark-cutting beef - a review
}

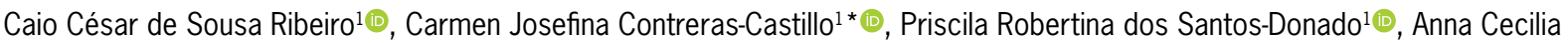 \\ Venturini2(1)
}

\author{
${ }^{1}$ Universidade de São Paulo/ESALQ - Depto. de \\ Agroindústria, Alimentos e Nutrição, Av. Pádua Dias, 11 - \\ Piracicaba, SP - Brasil. \\ ¿Universidade Federal de São Paulo - Depto. de Ciências \\ Farmacêuticas, R. São Nicolau, 210 - Diadema, SP - Brasil. \\ *Corresponding author <ccastill@usp.br>
}

Edited by: Paulo Cesar Sentelhas

Received March 25, 2020

Accepted July 12, 2020
ABSTRACT: Myoglobin (Mb) is a sarcoplasmic heme protein present in muscle cells, which acts as a short-term oxygen $\left(\mathrm{O}_{2}\right)$ reserve in the muscle tissue. After slaughtering and exsanguination, $\mathrm{Mb}$ is the major pigment that provides the red color in meat. The concentration of $\mathrm{Mb}$ together with its redox state are two pivotal factors that determine meat color. The elevated $\mathrm{pH}$ of dark-cutting beef can affect both physical and biochemical properties resulting in decreased oxygenation. The darkening observed in high ultimate $\mathrm{pH}\left(\mathrm{pH}_{\mathrm{u}}\right)$ beef concerns meat processors as color is the initial attribute that impacts on the purchase. Thus, any atypical meat color (i.e., loss of brightness) reduces consumer interest in the product. Several studies have demonstrated that immunological castration is effective in preventing both aggressive behavior and undesirable dark-cutting of bull meat. However, little information is available on the effects of processing techniques that limit the oxidation of ferrous iron $\left(\mathrm{Fe}^{2+}\right)$, $\mathrm{Mb}$ or promote metmyoglobin (MMb) reduction in dark-cutting beef. Because of the importance of color to fresh beef marketability, this review aimed at overviewing the significance of $\mathrm{pH}_{u}$ in beef color and color stability and to discuss new alternatives for improving and assessing the beef color of dark-cutting beef, especially in Nellore bulls and their crossbreds, which are widely used in beef cattle production in Brazil.

Keywords: $\mathrm{MMb}$ reductase enzyme, high $\mathrm{pH}_{\mathrm{u}}$, ultimate $\mathrm{pH}$, meat quality, bull

\section{Introduction}

Brazil is one of the world's largest beef producers (Associação Brasileira das Indústrias Exportadoras de Carnes - ABIEC, 2019), producing a total of 8.23 million tons in carcass-weight equivalent in 2019 (Instituto Brasileiro de Geografia e Estatística - IBGE, 2019, 2020). Of this total, $80.9 \%$ was destined for domestic consumption, providing an annual consumption of approximately $42 \mathrm{~kg}$ per capita (ABIEC, 2019). Bos indicus genetics, mainly the Nellore breed, have a considerable share of the Brazilian cattle herd (Mueller et al., 2019), in which males represent $59.1 \%$ of the total cattle slaughtered in Brazil during 2019 (IBGE, 2019, 2020).

The irritable behavior of bulls as well as other biological and environmental elements may impair proper muscle acidification until achieving the ultimate $\mathrm{pH}\left(\mathrm{pH}_{\mathrm{u}}\right)$ of $5.3-5.8$ (Ponnampalam et al., 2017), which is considered the normal $\mathrm{pH}_{\mathrm{u}}$ range (Ouali et al., 2006; Contreras-Castillo et al., 2016). Indeed, an ultimate $\mathrm{pH}$ above 5.8 is detrimental as it enhances the darkening of beef, which is known as dark-cutting beef (Tang et al., 2005; McKeith et al., 2016).

Dark-cutting beef results either from reduced myofibrillar shrinkage (i.e., lower light scattering) (Hughes, 2019) or from higher myoglobin (Mb) content (Ponnampalam et al., 2017). A high pHu then inhibits the $\mathrm{Mb}$ oxidation from developing a brown layer of metmyoglobin (MMb) due to improved metmyoglobin reducing activity (MRA) and consequent stability of the surface dark red color (Bekhit and Faustman, 2005).

Darkening is also attributable to increased mitochondrial oxygen consumption rate (OCR), which depletes the cellular oxygen $\left(\mathrm{O}_{2}\right)$ content and is amplified in high pHu muscles (Tang et al., 2005). Accordingly, higher $\mathrm{pHu}$ favors the formation of the purplish deoxymyoglobin (DMb) at the expense of the bright red oxymyoglobin $(\mathrm{OMb})$ on the surface of the muscle (Mancini and Hunt, 2005). The negative consequence of this undesirable effect, dark cutting beef, is less marketable (Suman et al., 2014).

Since dark cutting beef has a negative impact on the fresh beef market and consumer acceptance, an understanding of the biochemical reactions and pathways is necessary in order to mitigate this effect. Thus, the objectives of this review were to provide an overview of the significance of $\mathrm{pH}_{\mathrm{u}}$ on beef color and color stability and to discuss new alternatives aimed at improving and assessing the beef color of dark-cutting beef, especially for Nellore bulls and their crossbreds, which are widely used in beef cattle production in Brazil.

\section{Beef ultimate $\mathrm{pH}$}

After slaughtering, the $\mathrm{pH}_{\mathrm{u}}$ is reached after stabilization of the drop in $\mathrm{pH}$. Although $\mathrm{pH}$ measurements at $24 \mathrm{~h}$ postmortem may be conducted on group beef muscles (Li et al., 2014; Ponnampalam et al., 2017; Pulford et al., 2008; Renerre, 1990), $\mathrm{pH}_{\mathrm{u}}$ seems to stabilize only after $48 \mathrm{~h}$ postmortem in longissimus lumborum muscles. In fact, a decline in $\mathrm{pH}_{\mathrm{u}}$ values was observed when measured repeatedly at $24 \mathrm{~h}$ and at $48 \mathrm{~h}$ postmortem; and this continuous drop profile until $48 \mathrm{~h}$ postmortem was presented by Ouali et al. (2006) and Mlynek et al. (2012). 
There is a global incidence of beef muscle with $\mathrm{pH}_{\mathrm{u}}$ higher than the normal threshold established by experts and the beef industry. For instance, Mach et al. (2008) reported an incidence of $13.9 \%$ within $\mathrm{pH}>$ $5.8,24 \mathrm{~h}$ postmortem in Spain. According to ContrerasBarón (Personal communication), most of the cattle slaughtered in Brazil has shown $\mathrm{pH}$ above $5.848 \mathrm{~h}$ postmortem, which, to a certain extent, may impact the exporting of beef from Brazil. Nevertheless, there are still no records on the incidence of abnormal $\mathrm{pH}$ in meat in the Brazilian slaughter system.

To achieve a broader understanding on the influence of the high $\mathrm{pHu}$ on beef color, an initial overview on how $\mathrm{pH}$ drops to a determined $\mathrm{pHu}$ is required. Furthermore, the factors that can lead to a high $\mathrm{pHu}$ muscle and the definition of a $\mathrm{pHu}$ range to establish a cut-off standard are of pivotal importance.

\section{Biochemical basis of ultimate $\mathrm{pH}$}

Living muscle has a neutral $\mathrm{pH}(7.2$ - 7.4). After animal exsanguination, the delivery of $\mathrm{O}_{2}$ to muscle cells is interrupted. The depletion of $\mathrm{O}_{2}$ impairs the ability of cells to metabolize glucose aerobically by the tricarboxylic acid cycle and the respiratory chain. Glucose generated from muscle glycogen must be metabolized by glycolysis to generate lactate and $\mathrm{H}^{+}$together with adenosine triphosphate (ATP), whose hydrolysis boosts the $\mathrm{H}^{+}$ion concentration and thereby decreases the intracellular $\mathrm{pH}$ (England et al., 2016; Scheffler et al., 2015).

The $\mathrm{pH}$ drop profile does not present continuous behavior, but this profile passes through phases of transient $\mathrm{pH}$ stability until reaching the $\mathrm{pH}_{\mathrm{u}}$ (Ouali et al., 2006). Ouali et al. (2006) observed the gradual pH drop in two 19month-old Charolais bulls' longissimus muscle over the 0 $10 \mathrm{~h}$ post-slaughter period. The authors associated these $\mathrm{pH}$ drop profiles with the phospholipid-dependent inversion of polarity in cellular membranes. This phenomenon involves the electronegative phosphatidylserine groups switching to the external leaflet of the membrane, while the electropositive phosphatidylcholine and phosphatidylethanolamine groups change to the internal leaflet when apoptosis occurs in muscle cells. This switching causes transient partial neutralization of protons formed from glucose by glycolysis (Ouali et al., 2006).

Muscle glycolytic potential is the molar sum of all substrates of glycolysis (glycogen, glucose and lactate). Many researchers have demonstrated the negative correlation between the glycolytic potential and $\mathrm{pH}_{\mathrm{u}}$ (Holdstock et al., 2014; McKeith et al., 2016; Wulf et al., 2002). However, the type of fiber in the muscle may be a major determinant, as described in section 2.2.

\section{Biological and environmental effects on $\mathrm{pH}_{\mathrm{u}}$ dropping}

Several pre-harvest elements may determine the extension of $\mathrm{pH}$ drop. Physiological factors include the types of the myofiber and the muscle, as well as the testosterone level (Fink et al., 2018). Environmental factors involve the type of finishing, diet, and preslaughter stress, such as physical exercise, inadequate handling, and fighting between animals immediately prior to slaughter (Dunne et al., 2011; Ponnampalam et al., 2017).

Ultimate $\mathrm{pH}$ may vary according to the type of fiber that comprises a muscle. As stated by Patten et al. (2008) and England et al. (2014), glycolytic fibers, such as type IIB, present a fast glycolysis rate, which is able to produce a high concentration of ATP - substrate to $\mathrm{H}^{+}$production. Greater concentration of glycogen on glycolytic fibers favors the acidification that provides sufficient amount of substrate. Therefore, in glycolytic muscles, the $\mathrm{pH}$ reduction is inversely correlated to the initial concentration of glycogen in the muscle (Lawrence et al., 2012).

Ultimate $\mathrm{pH}$ closer to the typical range $(5.4-5.8)$ inhibits the activity of the glycolysis-regulatory enzyme phosphofructokinase, which ends the metabolic process, and then the $\mathrm{pH}$ drop in glycolytic fibers (England et al., 2014). Thus, glycolysis is active until the medium reaches an acidic $\mathrm{pH}_{\mathrm{u}}$ Conversely, oxidative fibers, such as type I, seem to have a shorter glycolysis pathway before reaching the necessary $\mathrm{pH}$ to inhibit the phosphofructokinase activity. Higher $\mathrm{pH}_{\mathrm{u}}$ in oxidative fibers may occur under two conditions: reduced glycogen content in the cell with low final ATP production, and a slow rate of glycolysis, which does not produce $\mathrm{H}^{+}$ions given the extent to which the enzyme is inhibited at $\mathrm{pH}$ close to 5.8, even when there is an excess of glycogen (England et al., 2016).

As reviewed by Seideman et al. (1982) and reported by Wȩglarz (2010), bulls have been classically known to produce beef with higher $\mathrm{pH}_{\mathrm{u}}$. The bull's excitable temperament encompasses both aggressive and sexual activities, and it is linked to the testosterone level (Seideman et al., 1982). Testosterone stimulates the animal, which depletes the muscle content of glycogen prior to slaughter, thus interrupting the proper muscle acidification.

On the other hand, reports have shown that different categories of animal temperament do not result in different $\mathrm{pH}_{\mathrm{u}}$ values (King et al., 2006). However, the degree of pre-slaughter stress should be taken into account because when stressful conditions are minimized or avoided, bulls do not produce elevated $\mathrm{pH}_{\mathrm{u}}$. Even though the longissimus dorsi muscles from bulls have appeared darker compared to steers, DeVol et al. (1985) found no correlation between the excitatory effect of testosterone on muscle color because there was no $\mathrm{pH}_{u}>5.8$ (5.66 for bulls and 5.58 for steers) nor any correlation between these $\mathrm{pH}_{\mathrm{u}}$ values. Therefore, this result was associated with pre-slaughter stress.

Extensive exercise and/or grass feeding is reported to enhance significant changes in muscle fiber 
composition, as these factors increase the proportion of the oxidative fibers (MyHC-IIa) at the expense of the glycolytic type (MyHC-IIx) (Gagaoua et al., 2017). As previously described, oxidative fibers have a slower rate and limited extent of $\mathrm{pH}$ drop and, subsequently, greater production of dark meat. Although the high $\mathrm{pH}_{\mathrm{u}}$ after pasture has been associated with lower intracellular glycogen content and decreased glycolytic potential the shift towards oxidative fibers reveals that the lower energetic potential is not the preponderant factor in dropping the $\mathrm{pH}$ (Apaoblaza et al., 2020; Picard and Gagaoua, 2020).

The nutrient restriction seems to increase the proportion of oxidative fiber type in the muscle and deplete the intracellular glycogen concentration (Bray et al., 1989; Kandeepan et al., 2009). Both conditions lead to less $\mathrm{H}^{+}$ions produced during the rigor mortis process (i.e., high $\mathrm{pH}_{\mathrm{u}}$ meat).

Understanding how pre-slaughter circumstances impact on the achievement of muscles with normal $\mathrm{pH}_{\mathrm{u}}$ and the economic consequences of postmortem biochemical reactions is a means of fomenting good animal welfare and ethical issues.

Animal stress may be avoided by a handler's careful perception of animal behavior prior to and/or during slaughter, especially if there are signs of fear, pain, and distress (Grandin, 2010, 2019). According to Bomzon (2011), cattle may disguise signs of pain so as not to demonstrate weakness in front of a possible predator. However, changes in cattle mobility, behavior and/or appearance may indicate poor welfare, such as lameness, falling during handling, vocalization, apparent sclera (the white of the eye), struggling, agitation and slipping in the stunning box, and body lesion (Bomzon, 2011; Grandin, 2010, 2019).

Vocalization above a certain level is a clear indicator of pain or stress and can be perceived by the handler while moving cattle or holding them restrained during slaughter. However, certain bulls in a herd, normally vocalize at the lairage even in the absence of stressful conditions. Vocalizing animals show increased blood concentration of the stress biomarker cortisol, lactate, and glucose, indicating glycogenolysis (Grandin, 2019). The neuropeptide $P$ level also increases when painful procedures are inflicted (Coitzee et al., 2008).

The frequent and gentle animal handling on the farm as well as the previous experience of moving into a veterinary restraint encourage cattle to become accustomed to the presence of humans and to walking to the slaughter box at the abattoir (Probst et al, 2013; Grandin, 2019). When this approach is adopted, animals can be cajoled into a calmer and fearless behavior right up to the slaughter procedure itself.

\section{Ultimate $\mathrm{pH}$ ranges}

Meat $\mathrm{pH}_{\mathrm{u}}$ ranges from 5.3 to over 7.0 , as reported by several authors (Abril et al., 2001; Contreras-Castillo et al., 2016; Hunt and Hedrick, 1977; Lawrie, 1958; McKeith et al., 2016; Pulford et al., 2008). Nevertheless, grouping $\mathrm{pH}_{\mathrm{u}}$ into ranges is a challenging task and there is no universal consensus, which results in several classifications and cut-off values.

Studies have focused on the meat tenderness of longissimus muscles, and a number of authors have grouped $\mathrm{pH}_{\mathrm{u}}$ into three ranges: normal $(<5.8)$ intermediate $(5.9-6.2)$ and high $(>6.20)$ (Lomiwes et al., 2014; Wu et al., 2014, Contreras-Castillo et al., 2016). This can be attributable to the meat tenderness observed in the three groups, in which the intermediate range is tougher than the other ones (Lomiwes, et al., 2013; Pulford et al., 2008). However, these ranges which assess meat tenderness cannot be applied to meat color studies.

As regards meat color, different classifications are proposed to group beef muscles according to their values of $\mathrm{pH}_{\mathrm{u}}$. For instance, Viljoen et al. (2002) and Park et al. (2007) considered $\mathrm{pH}_{\mathrm{u}}>5.8$ as a single group to be studied. On the other hand, McKeith et al. (2016) split high $\mathrm{pH}_{\mathrm{u}}$ carcasses into four classes for longissimus thoracis muscles, according to their dark color: shady $\left(\mathrm{pH}_{\mathrm{u}}: 6.1 \pm 0.03\right)$, mild (6.4 \pm $0.03)$, moderate $(6.6 \pm 0.03)$, and severe (6.9 \pm 0.03$)$. Holdstock et al. (2014) used $\mathrm{pH}_{\mathrm{u}} 6.0$ as the threshold for classifying beef muscles as normal $\left(\mathrm{pH}_{\mathrm{u}}<6.0\right)$ and typically dark $\left(\mathrm{pH}_{\mathrm{u}}>6.0\right)$.

One approach to reducing the human effect on $\mathrm{pH}_{\mathrm{u}}$ range classification is based on cluster analysis (Abril et al., 2001). This statistical technique involves analyzing the experimental data collected on the basis of their proximity - forming a group of samples with similar characteristics. This tool can show that data from the parameters assessed from three $\mathrm{pH}_{\mathrm{u}}$ muscle ranges can behave as two groups of $\mathrm{pH}_{\mathrm{u}^{\prime}}$ which increases the credibility of data analysis. Abril et al. (2001) applied cluster analysis to all the color coordinates and divided the samples into two groups according to their $\mathrm{pH}_{\mathrm{u}}: \mathrm{pH}_{\mathrm{u}}$ $<6.1$ and $\mathrm{pH}_{\mathrm{u}}>6.1$. This difference was also observed in the reflectance spectra.

\section{Dark-cutting beef and color stability}

A typical denomination for beef darkening is darkcutting beef. Certain authors have also referred it as DFD beef (Dark, Firm and Dry). Since the term firm might be interpreted as tough, it is important to note that not every high $\mathrm{pH}_{\mathrm{u}}$ muscle is tough. Because of enzymatic action by calpain proteases, meats with high $\mathrm{pH}_{\mathrm{u}}$ (especially above 6.3) can be as tender as those with normal $\mathrm{pH}_{\mathrm{u}}$ (Lomiwes et al., 2013). Therefore, the "dark-cutting" term seems more appropriate for studies focused on color.

Researchers have reported that $\mathrm{pH}_{\mathrm{u}}>5.8$ may result in dark meat (Abril et al., 2001; Ashmore et al., 1972; Holdstock et al., 2014; Hunt and Hedrick, 1977; Page et al., 2001; Stackhouse et al., 2016). Because of the 
global incidence of dark-cutting beef and its importance to the quality of meat, a broad consideration of the causal and consequential aspects involved may reveal gaps in the literature that require further investigation.

Moore et al. (2012) reported that $3.2 \%$ of the carcasses evaluated in the 2011 United States' National Beef Quality Audit were dark. The Beef Cattle Research Council - BCRC (BCRC, 2018) reported the incidence of dark cuts in Canada has been increasing: $0.84 \%$ in $1998 / 99,1.28 \%$ in 2010/11, and $1.64 \%$ in 2016/17. In relation to the incidence of $\mathrm{pH}_{\mathrm{u}}$ higher than 5.8 in the Brazilian beef industry, Rosa et al. (2016) studied 485 F1 crossbred animals (Nellore $\times$ South African Simmental) and according to the data, $4.53 \%$ of the animals $(\mathrm{n}=$ 22) presented $\mathrm{pH}>5.8$ and the meat color was darker than that of animals with normal $\mathrm{pH}_{\mathrm{u}}$. Although the percentage was not so high, given the volume of beef carcasses marketed worldwide, a reduced percentage of the occurrence of undesirable color represents serious loss for the meat industry, as stated by Hughes et al. (2014a).

As reported by Page et al. (2001), dark-cutting beef is highly correlated with $\mathrm{pH}_{\mathrm{u}}(\mathrm{r}=0.80)$. Authors showed that $91.7 \%$ of the muscles with $\mathrm{pH}_{\mathrm{u}} \geq 5.87$ were classified as dark cutters, following USDA grading standards, whereas in muscles with normal $\mathrm{pH}_{\mathrm{u}^{\prime}}$ the proportion was $0.6 \%$. Nonetheless, an atypical darkening may occur in normal $\mathrm{pH}_{\mathrm{u}}$ muscles. Holdstock et al. (2014) reported three groups of longissimus thoracis beef muscles: a) Canada AA carcass muscles (Japanese Meat Grading Association - JMGA - with a score of 3.50 and muscle $\mathrm{pH}$ of $5.57, \mathrm{n}=10$ ); b) Canada B4 carcass muscles, grouped into 1) atypical dark cutters (JMGA of 6.80 and muscle $\mathrm{pH}$ of $5.83, \mathrm{n}=10$ ), and 2) typical dark cutters (JMGA of 7.75 and muscle $\mathrm{pH}$ of $6.62, \mathrm{n}=10$ ). JMGA has a range from 1 (lightest color) to 8 (dark cutter). Both AA muscles and atypical dark cutter presented high glycosidic potential, which facilitates a proper $\mathrm{pH}$ drop to normal $\mathrm{pH}_{\mathrm{u}}$. Darkening can be associated with both physical (Jerez-Timaure et al., 2019) and biochemical effects and/or reactions (Wills et al., 2017).

\section{Effects of dark-cutting on the beef physical properties}

Meat color perceived by the consumer is the result of the combination of the light reflected and absorbed by or scattered on the surface of the meat. Redness attributes tend to be strongly associated with the $\mathrm{Mb}$ pigment, while brightness (light intensity) is related to the structural attributes of the muscle, which together determine the light reflected (Hughes et al., 2014b). Ultimate $\mathrm{pH}$ is one of the most important intrinsic factors in myofibril structure (Abril et al., 2001), which is demonstrated by the expressive correlation between the increase in muscle $\mathrm{pH}$ and extracellular space (Ouali et al., 2006).
Dark-cutting beef with high $\mathrm{pH}_{\mathrm{u}}$ undergoes minimal shrinkage in the myofibril structure. This alteration in the meat microstructure leads to an increase in hydration capacity by muscle proteins, also defined as water holding capacity (WHC). The greater content of water inside the muscle structure reduces the light scattered by the muscle fibers, which makes the meat surface look darker (Hughes et al., 2019).

Myofibrillar structural darkness has a great impact on beef marketability. However, the most significant attribute in purchasing is meat redness (Venturini et al., 2014). The intensity of redness is dependent on the presence, concentration and chemical state of the central pigment of beef tissue: myoglobin (Mancini and Hunt, 2005).

\section{Influencing factors on myoglobin concentration in dark-cutting development}

Similar to the determination of the $\mathrm{pH}_{\mathrm{u}}$ value, $\mathrm{Mb}$ concentration may be affected by both intrinsic (biological) and extrinsic elements. Endogenous components comprise bovine genetics, animal age, testosterone concentration, muscle type, and fiber involved. A noteworthy environmental influence on beef $\mathrm{Mb}$ concentration is the type of cattle, which dictates the frequency and extent of physical exercise.

King et al. (2010) demonstrated that genetic plays a role in $\mathrm{Mb}$ content in longissimus thoracis muscles. Seven steer breeds were investigated: Angus, Charolais, Gelbvie, Hereford, Limousin, Red Angus, and Simmental. Simmental showed the greatest concentration of $\mathrm{Mb}\left(3.71 \mathrm{mg} \mathrm{g}^{-1}\right)$, whereas Charolais and Limousin had significantly lower $\mathrm{Mb}$ values $(2.77$ and $2.72 \mathrm{mg} \mathrm{g}^{-1}$, respectively).

DeVol et al. (1985) demonstrated the effect of age on the darkening of longissimus dorsi muscles from bulls and steers from Limousin and Angus genotypes. The authors reported that the muscles of bulls were visually darker ( $\mathrm{p}<0.01$ ) with $3.25 \mathrm{mg} \mathrm{g}^{-1}$ of $\mathrm{Mb}$ content in fresh muscle, whereas the muscles of steers had $2.90 \mathrm{mg} \mathrm{g}^{-1}$ of $\mathrm{Mb}(\mathrm{p}<0.01)$. As animals get older, the amount of $\mathrm{Mb}$ increases but the affinity of $\mathrm{O}_{2}$ for $\mathrm{Mb}$ decreases; thus, they need to synthesize more $\mathrm{Mb}$ to stock $\mathrm{O}_{2}$. This explains why meat from older animals looks darker than meat from younger animals.

Although stress can significantly trigger the darkcutting, the high proportion of oxidative fiber types within muscles is the main factor that determines the susceptibility of animals to triggering this effect (Ponnampalam et al., 2017). Based on the activity of myosin ATPase, fiber types within muscles can be classified as red, intermediate, and white fibers (Voisinet et al., 1997).

Red fibers, involved in oxidative metabolism, have higher $\mathrm{Mb}$ contents and capillary blood flow than white ones, which maintain the $\mathrm{O}_{2}$ supply to cells. These two characteristics allow red fiber to oxidize glucose via 
aerobic pathways, which is corroborated by the larger number of mitochondria and tricarboxylic acid enzymes in muscle cells (Choi and Kim, 2009). Moreover, the increased content of $\mathrm{Mb}$ in oxidative fiber has been correlated with higher cytochrome c oxidase expression, which is present in the mitochondria and discernibly impacts on color stability (Apaoblaza et al., 2020).

Intermediate fibers have an oxidative-glycolytic metabolism and are intermediate between red and white fibers which have a glycolytic metabolism (Choi and Kim, 2009; Zerouala and Stickland, 1991). In other words, it is the ratio of red and intermediate fibers to white fibers that matters: muscles with high oxidative metabolic activity, where there is a predominance of $\beta$ and $\alpha$-red fibers, have a high risk of dark-cutting because their fibers tend to have greater affinity with circulating adrenaline which depletes glycogen more easily with the same level of activity or stress compared to an animal with $\alpha$-white muscle fibers (McGilchrist et al., 2012).

White fibers have a glycolytic metabolism and the least $\mathrm{Mb}$ concentration compared to the other two fibers because of the reduced $\mathrm{O}_{2}$ demand by cells. The lower abundance is related to the reduced stress undergone by glycolytic muscles, which are used for fast bursts of energy (Choi and Kim, 2009; Wicks et al., 2019).

In general, muscles with high oxidative metabolic activity, where there is more than $40 \%$ of slow oxidative red fibers, such as psoas major muscles, exhibit higher $\mathrm{Mb}$ concentration $\left(4.66 \pm 0.31 \mathrm{mg} \mathrm{g}^{-1}\right)$, higher content of mitochondria and thus more intense respiration, and are characterized as muscles with less color stability. In contrast, muscles comprising more than $40 \%$ of fast glycolytic white fibers, such as longissimus lumborum, have lower $\mathrm{Mb}$ concentration (3.97 $\left.\pm 0.12 \mathrm{mg} \mathrm{g}^{-1}\right)$, lower concentration of mitochondria and thus high color stability (Kirchofer et al., 2002; Salim et al., 2019).

Endogenous testosterone and steroidal compounds, such as trenbolone acetate, supplemented in diet or implanted in the animal trigger the growth of muscle fibers (Johnson and Chung, 2007). Fink et al. (2018) reported larger fiber cross-sectional area in bull muscles than in neutered males and females. Moreover, testosterone may also stimulate the prenatal enlargement and proliferation of the muscle cells, although postnatal cell formation is inhibited (Johnson and Chung, 2007; Wicks et al., 2019).

Nevertheless, hypertrophic pressure enlarges preferentially type IIB glycolytic fibers rather than type I oxidative fibers. Therefore, anabolic hormones and their analogues tend to generate muscles proportionally more glycolytic and thus lighter because of the lower $\mathrm{Mb}$ content (Wicks et al., 2019). Vaughn et al. (2019) found the growth of the glycolytic muscle longissimus was related to the extent of the proliferative capacity of satellite cells, which are muscle stem cells that continue to induce postnatal hypertrophy in myofibrils. Therefore, the darker color attributable to non-castrated cattle is likely related to the high $\mathrm{pHu}$-dependent change in muscle microstructure rather than higher intracellular $\mathrm{Mb}$ concentration.

The shifting in the muscle fibers stimulated towards greater proportion in response to pasturefinishing boosts intracellular $\mathrm{Mb}$ concentration as a consequence (Dunne et al., 2011; Picard and Gagaoua, 2020). This conversion is also stimulated by long-term physical exercise, as observed by Dunne et al. (2005) as well as by the grass-fed nutritional plane (Apaoblaza et al., 2020; Wicks et al. 2019). The resultant increase in $\mathrm{Mb}$ content is a response to the high demand of $\mathrm{O}_{2}$ by the mitochondrial oxidative metabolism. As observed by Apaoblaza et al. (2020), even glycolytic muscles such as longissimus dorsi, show greater $\mathrm{Mb}$ concentration after grass feeding compared to grain feeding, with significant darkening (lower instrumental lightness - $\mathrm{L}^{*}$ by Commission Internationale de l'Eclairage (CIE) in the longissimus muscle).

\section{Myoglobin structure and ligands}

Structurally, $\mathrm{Mb}$ is composed of a polypeptide chain and a group of $\mathrm{Fe}^{2+}$ protoporphyrin called heme. Heme consists of a tetrapyrrolic ring with conjugated double bonds, which binds coordinately to an $\mathrm{Fe}^{2+}$ (American Meat Science Association -- AMSA, 2012). The resonant electronic distribution of these conjugated bonds can absorb visible light and enhance the $\mathrm{Mb}$ color. Hematinic iron forms six-coordinate bonds. Four of these bonds have heme pyrrole nitrogen molecules in the same plane. The fifth coordination involves the interaction between iron and proximal histidine, located at position 93 (His93) (Møller and Skibsted, 2006). The sixth site of heme is available for reversible binding with a small ligand, such as $\mathrm{O}_{2}$, nitric oxide (NO) and carbon monoxide (CO). Fifth and sixth bonds are perpendicular to the heme ring. Hematinic iron may bind to $\mathrm{O}_{2}$ as a result of Mb's hydrophobic pocket, which is proper to the heme location. Inside this pocket, the accessibility of the heme group to solvent is highly restricted, which protects iron from oxidation. Bound to iron, oxygen forms a hydrogen bond to distal histidine (His64), which improves its bond (Mancini and Hunt, 2005).

The three states of $\mathrm{Mb}$ present in the fresh muscle interchange simultaneously under natural conditions in the retail store or at home, and the conversion takes place in dynamic equilibrium. A higher proportion of one pigment is dependent on intrinsic and environmental factors, such as meat $\mathrm{pH}_{\mathrm{u}^{\prime}}$ MRA, lipid oxidation, gas composition, temperature, and microbial growth (Mancini and Hunt, 2005).

\section{Biochemical basis of color stability}

The superficial dynamic equilibrium between $\mathrm{DMb}$, $\mathrm{OMb}$, and $\mathrm{MMb}$ over a period of time defines muscle color stability, which can be impaired depending on 
internal and external conditions favoring the prevalence of one form on the muscle surface (Bekhit and Faustman, 2005).

Functionality of mitochondria plays a critical role in the intensity and stability of color from the postmortem aging muscle (Ma et al., 2017). Respiratory consumption of $\mathrm{O}_{2}$ generates reactive oxygen species (ROS) as by-products. Lipids and proteins are the main targets and are involved in the oxidation of $\mathrm{Fe}^{2+}-\mathrm{Mb}$ to $\mathrm{Fe}^{3+}-\mathrm{Mb}$ and thus increase muscle $\mathrm{MMb}$ content (Tang et al., 2005). Nevertheless, the mitochondria also possess the ability to convert MMb back to DMb (Bekhit and Faustman, 2005).

High OCR in the initial periods of the postmortem is deleterious to the development of the surface bright red color since mitochondrial respiration outcompetes $\mathrm{Mb}$ for $\mathrm{O}_{2}$ and ultimately results in dark colored muscle (Suman et al., 2014). Over time, there is an improvement in color development because of the decrease in OCR. The depletion of substrates for OC, such as lactate, succinate, and the reduced state of nicotinamide adenine dinucleotide $(\mathrm{NADH})$, during storage time makes $\mathrm{O}_{2}$ diffuse more rapidly through the tissue in order to bind to $\mathrm{Mb}$, which improves color development and stability (MacDougall, 1982; Mancini and Ramanathan, 2014).

The improvement in the superficial color of meat aged in the short-term can be attributed to a decrease in the OCR of substrates and enzyme activity in the mitochondria (Ramanathan et al., 2013; Seyfert et al., 2006). On the other hand, long-term aging reduces the potential for oxygenation (blooming) by decreasing mitochondria-mediated MRA, when aged beef is subsequently displayed under retail light conditions (Mancini and Ramanathan, 2014).

Cytochrome c oxidase (complex IV) has been reported to be essential to OCR (Grabež et al., 2015; Seyfert et al., 2006). This enzyme is located on the inner mitochondrial membrane and comprises the electron-transport chain along with complexes I (NADH oxidoreductase), II (succinate-Q reductase), and III (coenzyme Q-cytochrome c oxidoreductase) (Arihara et al., 1995).

Under oxidative condition, $\mathrm{MMb}$ generation occurs beneath the surface, between the superficial $\mathrm{OMb}$ and inner DMb layers. In the intermediate layer, the insufficient availability of $\mathrm{O}_{2}$ to oxygenate all available $\mathrm{DMb}$ creates a suitable condition for ROS molecules to initiate $\mathrm{O}_{2}$ oxidation, which can propagate this chain reaction (O'Keeffe and Hood, 1982). MMb can be formed precisely in the intermediate layer; the subsurface layer of $\mathrm{MMb}$ increases and moves towards the surface as the $\mathrm{OMb}$ layer on the surface becomes thinner and is replaced by the MMb layer (Mancini and Hunt, 2005).

Oxidation requires the prior deoxygenation of $\mathrm{OMb}$ so that $\mathrm{MMb}$ can be obtained. This precondition is due to the high resonant structure of OMb providing it with great oxidative stability, which makes $\mathrm{OMb}$ oxidation thermodynamically unfavorable (Faustman and Cassens,
1990). Once formed, MMb can be endogenously reduced to $\mathrm{DMb}$ either by enzymatic or non-enzymatic reactions and favors maintenance of ferrous forms of $\mathrm{Mb}$ in meat (Faustman et al., 2010). However, the enzymatic system is considered prominent.

Metmyoglobin reducing activity is an intrinsic cellular ability that will reduce $\mathrm{MMb}$ to $\mathrm{DMb}$, which can be oxygenated to $\mathrm{OMb}$ (Ramanathan et al., 2013). Because of this reversible characteristic, MRA seems to be critically important to maintaining or prolonging surface color stability. The increase in $\mathrm{MMb}$ proportion throughout retail time implies a decrease in MRA (Bekhit and Faustman, 2005).

Enzymatic MRA involves the NADHcytochrome b5 $\mathrm{MMb}$ reductase enzyme and is based on the transference of two electrons from an $\mathrm{NADH}$-coenzyme to a ferricytochrome b5, thus reducing it to ferrocytochrome b5. As an intermediate, ferricytochrome b5 non-enzymatically reduces $\mathrm{MMb}$ to $\mathrm{DMb}$, regenerating the content of oxidized cytochrome b5 and improving meat color (Arihara et al., 1995; Bekhit and Faustman, 2005; Zhai et al., 2019).

In non-enzymatic $\mathrm{MMb}$ reduction, an electron from $\mathrm{DMb}$ is transferred to MMb by an artificial electron carrier, such as NADH or NAPDH in the presence of ethylene c acidiaminetetraacetid (EDTA), cytochrome c, methylene blue, ascorbate, uridine diphosphate sugar (UDP-sugar), vitamin E, psychrotrophic bacteria and other systems (Bekhit and Faustman, 2005). In addition to the enzymatic process, non-enzymatic MMb reduction replenishes $\mathrm{NADH}$ through the added oxidized form of nicotinamide adenine dinucleotide $(\mathrm{NAD}+)$ and Krebs cycle intermediate substrates. However, non-enzymatic processes depend on the $\mathrm{O}_{2}$ intracellular content, which is inhibited under vacuum conditions (Ramanathan and Mancini, 2018).

Denzer et al. (2020) studied how these electron donors and carriers act in non-enzymatic $\mathrm{MMb}$ reduction in vitro with equine muscle $\mathrm{MMb}$ at meat $\mathrm{pH}$ $(5.2,5.6,6.0$, and 6.4$)$ and storage temperatures (4 and $25^{\circ} \mathrm{C}$ ). The authors used ascorbate and nicotinamide adenine dinucleotide, in a reduced form (NADH) as electron donors and methylene blue and cytochrome $\mathrm{c}$ as cofactors. Methylene blue in the presence of $\mathrm{NADH}$ or ascorbate was more reduced at $4{ }^{\circ} \mathrm{C}$ than at $25{ }^{\circ} \mathrm{C}$, with ascorbate and $\mathrm{NADH}$. Higher $\mathrm{pH}$ increased methemoglobin reduction with ascorbate and cytochrome c. These non-enzymatic data corroborated the greater enzymatic $\mathrm{MMb}$ reduction in high $\mathrm{pHu}$ range.

Despite Denzer et al. (2020) obtaining results from equine muscle MMb, Bechtold et al. (2019) found that the non-enzymatic $\mathrm{MMb}$ reduction was higher in bovine samples than in equine counterparts.

Metmyoglobin reducing activity and $\mathrm{NADH}$ can be gradually depleted throughout storage/display time (Mancini and Hunt, 2005). Kim et al. (2009) observed a pattern for the decrease in lactate dehydrogenase (LDH) 
activity, NADH concentration and the percentage of MRA during the retail time of longissimus lumborum muscle packaged under fluorescent light for seven days covered with a polyvinylchloride (PVC) film. Furthermore, $\mathrm{MMb}$ may also be reduced via electrons from the mitochondrial electron-transport chain to form DMb (Belskie et al., 2015; Tang et al., 2005).

Canto et al. (2016) evaluated MRA in Nellore longissimus lumborum and psoas major packaged on polystyrene trays with $\mathrm{O}_{2}$-permeable film and stored refrigerated for nine days. The authors observed a progressive drop during all retail periods for both muscles. Longissimus lumborum showed more MRA than psoas major throughout the storage period. Similarly, other authors have reported an inverse correlation between MRA and meat discoloration (Bekhit and Faustman, 2005; Ledward, 1985; Mancini et al., 2008; Reddy and Carpenter, 1991; Seyfert et al., 2006).

Higher $\mathrm{MMb}$ reductase activity may explain the greater color stability shown by certain muscles, such as longissimus lumborum compared to psoas major, as observed by Canto et al. (2016) and Salim et al. (2019).

Several beef muscles were sorted by Renerre (1990) according to their oxidation stability: longissimus dorsi, obliquus externus and tensor fasciae latae were the most stable muscles. semi-membranosus had intermediate stability, while gluteus medius, supra-spinatus, psoas major and diaphragma medialis were the most prone to oxidation. Renerre's classification agrees with previous studies (Ledward, 1971; O'Keeffe and Hood, 1980-81).

To date, the relationship between MRA and discoloration is not consensual. Although Kim et al. (2009) found a decrease in MRA; these authors did not find an increase in surface $\mathrm{MMb}$ accumulation (\%) in beef steaks of longissimus lumborum stored for seven days at $1{ }^{\circ} \mathrm{C}$. According to Sammel et al. (2002), the lack of uniformity in the MRA methodologies could explain these contradictory findings.

\section{Color stability of dark-cutting beef}

Higher postmortem muscle $\mathrm{pH}$ is the most important factor that can prolong mitochondrial functionality (Ramanathan et al., 2019). Previous reports state that the mitochondria from dark-cutting beef has progressively greater $\mathrm{O}_{2}$ consumption and higher level of $\mathrm{MMb}$ reductase activity as the $\mathrm{pH}$ of dark-cutting meat increases (McKeith et al., 2016; Wu et al., 2020).

High $\mathrm{pH}_{\mathrm{u}}$ carcasses are reported to have greater mitochondrial OCR due to a higher activity in the enzyme cytochrome c oxidase (complex IV), which oxidizes $\mathrm{O}_{2}$ into water, resulting in less surface $\mathrm{OMb}$ and a darker color (Bendall and Taylor, 1972; Tang et al. 2005; Renerre, 1990). According to Bendall and Taylor (1972), mitochondrial $\mathrm{O}_{2}$ consumption is approximately $50-75 \%$ faster at $\mathrm{pH} 7.2$ than at $\mathrm{pH}$ 5.8. As a result, the conversion to the DMb redox form is favored at high $\mathrm{pH}_{\mathrm{u}^{\prime}}$ giving the meat a purplish color.
Muscle structure also contributes to color development by affecting $\mathrm{O}_{2}$ influx through the tissue, facilitating interaction between gas and $\mathrm{Mb}$ (Mancini and Hunt, 2005). A closed structure observed in high $\mathrm{pH}_{\mathrm{u}}$ muscles makes it difficult to diffuse $\mathrm{O}_{2}$ into the swollen muscle fibers due to the higher WHC (Hughes et al., 2014b; Mancini and Hunt, 2005). In addition, glycolytic fibers often have a smaller diameter, which is detrimental to $\mathrm{O}_{2}$ diffusion (Choi and Kim, 2009; Kirchofer et al., 2002).

The decrease in $\mathrm{O}_{2}$ concentration within the myofibrils favors the formation of DMb and the color of fresh beef turns to dark purple (Ramanathan et al., 2019). Since the $\mathrm{O}_{2}$ depth depends on the $\mathrm{O}_{2}$ concentration in the medium, oxygenation by means of air-exposition (approximately $20 \% \mathrm{O}_{2}$ ) would not result in a thick OMb layer on dark-cutting beef surfaces.

In addition to the $\mathrm{O}_{2}$ concentration, oxygenation also depends on the time and the temperature of exposition, blooming takes place more efficiently when meat is exposed to $\mathrm{O}_{2}$ at $0-2{ }^{\circ} \mathrm{C}$ for, at least, $30 \mathrm{~min}$. Higher temperatures increase mitochondrial activity and thus the $\mathrm{O}_{2}$ uptake, which reduces the $\mathrm{O}_{2}$ available to bind to $\mathrm{Mb}$ (Bendall and Taylor, 1972; Renerre, 1990).

The opposite phenomenon is observed in high $\mathrm{pH}_{\mathrm{u}}$ meat compared to MRA. These muscles show a protective effect on the oxidation of $\mathrm{Mb}$. As a result, dark-cutting beef is resistant to forming the brownish layer of $\mathrm{MMb}$ over time (Lu et al., 2020). In contrast to $\mathrm{OCR}$, the protective effect is endogenous and as regards the content of substrates, such as $\mathrm{NADH}$, the MMb reductase activity decays over time.

Therefore, at a certain point, the oxidative pressure by fluorescent illumination, the amount of ROS produced in mitochondrial respiration, or other factors will promote $\mathrm{Mb}$ oxidation that will be noticeable on the surface of the muscle (Bekhit and Faustman, 2005; Ramanathan et al., 2019; Renerre, 1990) which leads to lower discoloration over the display time because of the accumulation of $\mathrm{MMb}$ on the meat surface (Renerre, 1990). In short, low $\mathrm{O}_{2}$ tension, $\mathrm{pH}_{\mathrm{u}}$ up to 5.8, high temperature, concomitant lipid oxidation and loss of $\mathrm{MMb}$-reducing activity are amongst the factors that influence iron oxidation (Bekhit and Faustman, 2005; Mancini and Hunt, 2005). To prevent oxidation of DMb to $\mathrm{MMb}$, residual $\mathrm{O}_{2}$ within vacuum packaging should be avoided. At low $\mathrm{O}_{2}$ concentrations ( $<7 \mathrm{~mm} \mathrm{Hg}$ ) DMb is susceptible to oxidation by ROS, forming MMb. At $\mathrm{O}_{2}$ concentrations $>7 \mathrm{~mm} \mathrm{Hg}, \mathrm{O}_{2}$ competes with the peroxide radicals for the $\mathrm{DMb}$, inhibiting the formation of MMb (AMSA, 2012).

The role of $\mathrm{pH}$ in the rate of $\mathrm{MMb}$ formation has been the focus of research for quite some time. Chemically, iron-catalyzed oxidation has been reported to be more active under acidic conditions (George and Stratmann, 1952). Enzymatically, Echevarne et al. (1990) showed that $\mathrm{MMb}$ reductase activity increases as a function of the medium $\mathrm{pH}_{\text {, achieving its maximum }}$ 
activity at pH 7.3. Ramanathan et al. (2012) reported that a mitochondrial NADH-dependent reductase reduced more $\mathrm{MMb}$ in the control group at $\mathrm{pH} 7.4$ than at $\mathrm{pH}$ 5.6 ( $\mathrm{p}<0.05)$. The unbalanced equilibria among DMb, $\mathrm{OMb}$, and $\mathrm{MMb}$ in the high $\mathrm{pH}_{\mathrm{u}}$ muscles interfere with the visual and instrumentally measured surface color. Table 1 summarizes the data on the effect of high $\mathrm{pH}_{\mathrm{u}}$ on color attributes (instrumental, visual and color stability).

The most used instrumental colorimetric system to characterize color or evaluate color changes is the Commission Internationale de l'Eclairage (CIE) $\mathrm{L}^{*} \mathrm{a}^{*} \mathrm{~b}^{*}$, where $L^{*}$ measures lightness (0: black, 100: white), $a^{*}$ measures redness (-60: green, +60 : red), and $b^{*}$ measures yellowness (-60: blue, +60 yellow). Another system available is the HunterLab, such as the RGB (red, green and blue) models.

Redness $\left(\mathrm{a}^{*}\right)$ is reduced at a higher $\mathrm{pH}_{\mathrm{u}}$ due to a decreased accumulation in $\mathrm{OMb}$ on the muscle surface because of more intense cellular respiration (Bendall and Taylor, 1972; Tang et al., 2005). Page et al. (2001) found that muscle $\mathrm{pH}_{\mathrm{u}}$ was more correlated with $\mathrm{a}^{*}$ and $b^{*}$ values than with $L^{*}$ values. The authors stated that

Table 1 - Summary of studies on the effects of high ultimate $\mathrm{pH}$ on meat color.

\begin{tabular}{ll}
\hline Experimental material & High $_{\mathrm{u}}$ \\
LT from Bos taurus (Parda & \\
$\begin{array}{l}\text { Alpina (15) and Pirenaica (16) } \\
\text { breeds) }\end{array}$ & $>6.1$
\end{tabular}

LL from steers (680), heifers

(315) and bullocks (5).
Findings

CIE $L^{*}, a^{*}, b^{*}$, Chroma, and hue were affected by pHu $(p \leq 0.001)$. CIE $b^{*}$ is the best discriminant for $\mathrm{pH}_{u}$ groups. $\mathrm{pH}_{u}$ also had an effect on reflectance spectra during aging $(0 \mathrm{~min}, 5 \mathrm{~h}, 2 \mathrm{~d}$, and $9 \mathrm{~d})$. There was a dependence between $\mathrm{pH}_{\text {and }}$ the spectrophotometric indexes (K/S614 - K/S632, K/S 630 - K/S 580, and Ro6632 - Ro614) $(p \leq 0.001)$.

LL Beef from 24/1000 carcasses were grouped into $\mathrm{pH}_{u}>5.87$, with 22/24 carcasses classified as "dark cutters". Muscle $\mathrm{pH}_{u}$ had positive correlation with dark-cutting $(r=0.80)$ and negative correlation with $L^{*}(r=-0.40)$, $a^{*}(r=-0.58)$, and $b^{*}(r=-0.56)$.

LD from beef carcasses $\quad \geq 5.80 \quad \begin{aligned} & \text { High } \mathrm{pH}_{\mathrm{u}} \text { samples had lower sensory scores related to color than normal } \mathrm{pH}_{u} \\ & \text { samples }(p \leq 0.001)\end{aligned}$

High $p H$ carcasses presented LT with lower values of CIE $L^{*}, a^{*}$, and $b^{*}$ than

LT from Beef carcasses (47) av. 6.06 normal muscles $(p \leq 0.05)$. DFD LL and MST after 7 days postmortem $\left(\mathrm{pH}_{\mathrm{u}}>\right.$ 5.80) also showed lower $\mathrm{CIE} \mathrm{L}^{*}, a^{*}$, and $b^{*}$ than those of normal muscles $(p \leq 0.05)$.

$\begin{array}{lll}\begin{array}{l}\text { LL from Hanwoo steers and } \\ \text { bulls (24) }\end{array} & >5.80 & \begin{array}{l}\text { Positive correlation between beef color (lean meat) and } \mathrm{pH}_{u}(r=0.77) . \\ \text { According to } \mathrm{ClE} \mathrm{a}^{*} \text {, normal } \mathrm{pH}_{\mathrm{u}} \text { muscles were redder than the high } \mathrm{pH}_{u} \\ \text { group. }\end{array} \\ \begin{array}{l}\text { LT from young bulls (106), } \\ \text { bulls (96), cows (317), and } \\ \text { heifers (95) }\end{array} & \begin{array}{l}\text { pH negatively correlated with } \mathrm{L}^{*}(r=-0.24), a^{*}(r=-0.29), b^{*}(r=-0.24), \\ \text { Chroma }(r=-0.29), \text { and hue }(r=-0.30) .\end{array}\end{array}$

Park et al. (2007).

Viljoen et al. (2002).

Wulf et al. (2002).

Węglarz (2010).

High $\mathrm{pH}_{u}$ muscles had lower $\mathrm{L}^{*}, \mathrm{a}^{*}\left(\mathrm{CIEL}{ }^{*} \mathrm{a}^{*} \mathrm{~b}\right), \mathrm{R}, \mathrm{G}, \mathrm{B}(\mathrm{RGB}), \mathrm{V}$, and $\mathrm{L}$ values than normal $\mathrm{pH}_{4}$ muscles $(p \leq 0.05)$. Total heme pigment content did not increase in the high $\mathrm{pH}_{\text {g }}$ group. $\mathrm{pH}$ showed high correlation with $\mathrm{L}^{*}$ $(r=-0.80), R(r=-0.79), G(r=-0.69), B(r=-0.68), V(r=-0.79)$, and $L$ $(r=-0.77)$, and moderate correlation with $a^{*}(r=-0.44)$.

Muscles with $\mathrm{pH}_{u}>6.0$ were darker than those of the normal $\mathrm{pH}_{u}$ group based on JMGA $(p<0.05)$. Atypical DC muscles $\left(\mathrm{pH}_{u}<6.0\right)$ were also darker than those of the normal $\mathrm{pH}_{u}$ group. The correlation $\left(\mathrm{R}^{2}\right)$ between $\mathrm{pH}_{u}$ values and JMGA scores was 0.59 .

LT from 179 dark-cutting beef $>6.0$

LL from beef carcasses (10) aged during $62 \mathrm{~d}$ under vacuum (dark at $2^{\circ} \mathrm{C}$ ) av. 6.4 (all aging) $\mathrm{OMb}$ (during oxygenation period) for all aging times than those of the normal $\mathrm{pH}_{u}$ muscles.

Animal selection based on dark-cutting, with subsequent grouping into four

LL from steers and heifers. 9 - 30 months-old

sub-groups, with average $\mathrm{pH}_{\mathrm{u}}$ from 6.1 to 6.9. Instrumental color $\left(\mathrm{L}^{*}, \mathrm{a}^{*}\right.$, $\mathrm{b}^{*}$, Chroma, and hue) and color stability parameters (IMF and bloomed OMb) decreased as $\mathrm{pH}_{u}$ increased $(p \leq 0.05)$.

Non-enhanced dark-cutting muscles showed higher $\mathrm{pH}_{\text {than }}$ those of the normal $\mathrm{pH}_{u}$ group (USDA choice). High $\mathrm{pH}_{u}$ muscles (non-enhanced) were darker ( $\mathrm{L}^{*}$ and visual color), less red and had lower hue and Chroma values than non-enhanced normal $\mathrm{pH}_{u}$ muscles on initial retail time. Color parameters were more stable during retail time for high $\mathrm{pH}_{u}$ than those for the normal $\mathrm{pH}_{\mathrm{u}}$ group.
Chmiel et al. (2012).

Holdstock et al. (2014). LL from beef carcasses (9) av. 6.65 Muscles: $\mathrm{LL}=$ longissimus lumborum; $\mathrm{LT}=$ longissimus thoracis; $\mathrm{LD}=$ longissimus dorsi; $\mathrm{LTD}=$ latissimus dorsi; $\mathrm{RA}=$ rectus abdominis; $\mathrm{MSM}=$ semimembranosus;
$\mathrm{MST}$ = semitendinosus; $\mathrm{pHu}=$ ultimate $\mathrm{pH} ; \mathrm{DC}=$ dark cutting; $\mathrm{DFD}=$ dry, firm, and dark meat; $\mathrm{RGB}=$ computer vision system $(\mathrm{R}=$ red, $\mathrm{G}=$ green, $\mathrm{B}=$ blue); $\mathrm{V}$ and $\mathrm{L}$ $M S T=$ semitendinosus; $\mathrm{pHu}=$ ultimate $\mathrm{pH} ; \mathrm{DC}=$ dark cutting; $\mathrm{DFD}=$ dry, firm, and dark meat; $\mathrm{RGB}=$ computer vision system $(\mathrm{R}=\mathrm{red}, \mathrm{G}=\mathrm{green}, \mathrm{B}=\mathrm{blue}) ; \mathrm{V}$ and $\mathrm{L}$
$=$ value and lightness software models for color analysis; $\mathrm{CIE} \mathrm{L}^{*}\left(\right.$ lightness); $\mathrm{a}^{*}$ (redness); $\mathrm{b}^{*}$ (yellowness); av. = average; $\mathrm{K} / \mathrm{S}=$ ratio of absorptive $(\mathrm{K})$ and scattering (S) color properties; $\mathrm{R}_{\infty}=$ reflectivity; $\mathrm{OMb}=$ oxymyoglobin; $\mathrm{OCR}=$ oxygen consumption rate; MRA = metmyoglobin reducing activity; IMF = initial metmyoglobin formed; JMGA = Japanese meat grading association; USDA = The United States Department of Agriculture. 
$\mathrm{pH}_{\mathrm{u}}$ affected the muscle color by changing the hue angle. Reduction in hue angle values moves color attributes closer to the $+a^{*}$ axis (red) and farther from the $+b^{*}$ axis (yellow). It was concluded that the closer the hue angle was to $0^{\circ}$ and thus to $b^{*} 0$, the less the muscle was discolored. A number of authors have observed this decrease in angle and chroma as the $\mathrm{pH}_{\mathrm{u}}$ increased (Mckeith et al., 2016; Stackhouse et al., 2016; W glarz, 2010; Abril et al., 2001).

\section{Improving the color of dark-cutting beef}

Currently, vacuum-packaged meat is becoming more common because of its convenience for processors and consumers. However, vacuum-packaged muscles are dark and purplish in color due to the DMb layer on the surface, which can be easily oxygenated after adequate exposition to $\mathrm{O}_{2}$. A high $\mathrm{DMb}$ concentration is also observed in muscle immediately after cutting, since $\mathrm{O}_{2}$ penetration does not persist through the entire meat (Mancini and Hunt, 2005). The absence of $\mathrm{OMb}$ on a steak immediately after cutting is particularly useful for OCR analysis to measure $\mathrm{O}_{2}$ intake by mitochondria. The higher $\mathrm{O}_{2}$ partial pressure found in high oxygen modified atmosphere packaging (HiOx MAP) increases the depth of penetration of $\mathrm{O}_{2}$ through the muscle microstructure, which results in a thicker OMb layer on the muscle surface. Therefore, packaging dark-cutting beef in $\mathrm{HiOx}$ MAP is a strategy which can induce a bright red surface on the muscle despite the high pHu (McMillin, 2008; Renerre, 1990). Moreover, HiOx retards uprising in the $\mathrm{MMb}$ layer on the muscle surface (Mancini and Hunt, 2005), whereas steaks packaged with $\mathrm{O}_{2}$ permeable films can maintain the cherry red color for hours or a few days. Thus, beef with HiOx MAP can be displayed for 6 - 10 days only (McMillin, 2008), because of microbial spoilage (Sun and Holley, 2012).

Another strategy for improving the quality of dark-cutting meat is the use of carbon monoxide modified atmosphere packaging (CO-MAP). Beef with high $\mathrm{pH}_{\mathrm{u}}$ was shown to be lighter and redder in COMAP, but resulted in a higher surface $\mathrm{MMb}$ content than beef in HiOx MAP, which indicates that the relationship between MRA and $\mathrm{MMb}$ content in CO-MAP was different compared to that found in HiOx MAP (Zhang et al., 2018).

The use of carbon dioxide $\left(\mathrm{CO}_{2}\right)$ can inhibit the growth of food pathogens and Gram-negative aerobic bacteria, since they are more sensitive to $\mathrm{CO}_{2}$ compared to Gram-positive bacteria (Daniels et al., 1985). A higher proportion of $\mathrm{CO}_{2}$ can be used to package meat and prevent aerobic deterioration with an increase in microbial control (Sun and Holley, 2012).

Although the use of HiOx MAP increases consumer acceptance of meat color (O'Sullivan et al., 2015), this modified atmosphere has been associated with some loss in overall meat quality because of the presence of off-odors and off-flavors attributable to lipid oxidation
(Jayasingh et al., 2002). Seyfert et al. (2006) also found an increase in thiobarbituric acid reactive substance (TBARS) values of beef packaged in $\mathrm{HiOx}$ MAP after storage and display.

According to Ramanathan et al. (2012) and Suman et al. (2014), beef $\mathrm{Mb}$ is greatly susceptible to nucleophilic attack by ROS and aldehydes generated from peroxidation, such as 4-hydroxynonenal, which increases the proportion of $\mathrm{MMb}\left(\mathrm{Fe}^{3+}\right)$ on the beef surface. However, fresh steaks from Nellore bulls showed extremely low TBARS values in both $\mathrm{HiOx}$ MAP and CO-MAP (Santos et al., 2016). Fiber IIB exhibit glycolytic metabolism and pasture-fed zebu steers (longissimus lumborum muscles), and contains natural antioxidants, which may explain these results (Canto et al., 2016).

Research indicates that the addition of various glycolytic and tricarboxylic acid metabolites, such as succinate, lactate, and malate can regenerate $\mathrm{NADH}$ through NADH-dependent reducing systems to enhance $\mathrm{MMb}$ reduction and the color stability of whole-muscle beef cuts (Table 2).

Furthermore, the ability of pyruvate and succinate to minimize lipid oxidation has been reported (Ramanathan et al., 2011). Kim et al. (2006) reported that color stabilization by lactate enhancement is related to MRA, by NADH replacement via $\mathrm{LDH}$, reducing NAD + both enzymatically and non-enzymatically. However, $\mathrm{NADH}$ can also promote mitochondrial $\mathrm{O}_{2}$ consumption resulting in darkened muscle because of the lowering of $\mathrm{Mb}$ oxygenation (Ramanathan et al., 2019). Lactate also results in color stabilization of cooked beef (Knock et al., 2006). In addition, the application of solutions containing lactate improve the meat's juiciness, tenderness, taste, shelf life, and yield (Lawrence et al., 2003).

The addition of potassium lactate increased the color stability of steaks packaged in HiOx MAP (Kim et al., 2006). Additional research indicated the effect of lactate enhancement on beef steaks is packagingdependent (Suman et al., 2009): lactate can be utilized for improving the color stability of beef steaks in HiOx MAP, but has no effect on the beef color stored in vacuum packaging and CO-MAP. Many advances have been made in the field of active packaging, such as the detection of microbial spoilage and safety within different MAP systems, to which dark-cutting has increased susceptibility (Holman et al., 2018). Sensors for real-time monitoring of beef freshness and quality can be used as an attractive and effective tool for assessing the microbial quality of packaged fresh meat (Kuswandi and Nurfawaidi, 2017; Shukla et al., 2015).

\section{Color methods applied in dark-cutting beef fresh muscle}

Because of the difference in $\mathrm{pH}_{\mathrm{u}^{\prime}}$ certain research methods for evaluating meat color in high $\mathrm{pH}_{\mathrm{u}}$ beef samples require adaptations or a new approach to obtain 
Table 2 - Summary of results from studies that have examined the relationship between injection-enhanced beef with various Krebs cycle intermediates and the color stability.

\begin{tabular}{|c|c|}
\hline Results & References \\
\hline \multicolumn{2}{|c|}{$\begin{array}{l}\text { A combination of substrates relevant to mitochondrial oxygen consumption, improved meat color stability forms in aerobic and Bjelanovic et al. (2016). } \\
\text { anaerobic packaging systems. }\end{array}$} \\
\hline An acceptable beef color resulted from the infusion of beef muscles with a phosphate and lactate blend. & Erikson et al. (2018). \\
\hline $\begin{array}{l}\text { Lactate and rosemary in beef enhancement solutions for improving strip loin steak color stability during display in modified } \\
\text { atmosphere packages (HiOx MAP } 80 \% \mathrm{O}_{2} / 20 \% \mathrm{CO}_{2} \text { ). }\end{array}$ & Mancini et al. (2005). \\
\hline $\begin{array}{l}\text { Beef steaks enhanced with lactate, pyruvate, and succinate were less discolored than control steaks in PVC and high oxygen. } \\
\text { Succinate had the greatest and pyruvate had the least metmyoglobin-reducing activity. }\end{array}$ & Ramanathan et al. (2011a). \\
\hline Lactate-enhanced steaks had the least overall surface reflectance and the darkest surface color (lower L*). & Ramanathan et al. (2010). \\
\hline $\begin{array}{l}\text { Lactate can improve the color stability of lamb, possibly by increasing both oxygen consumption and metmyoglobin reducing } \\
\text { activity. }\end{array}$ & Ramanathan et al. (2011b). \\
\hline Effects of lactate on myoglobin are temperature and pH dependent. & Suman et al. (2014). \\
\hline $\begin{array}{l}\text { Calcium lactate/phosphate enhancement have beneficial effects on lipid stability, surface color, and sensory attributes of beef } \\
\text { round cuts under HiOx MAP. }\end{array}$ & Cruzen et al. (2015). \\
\hline $\begin{array}{l}\text { The glutamate, succinate and citrate combinations acted as pro-oxidants that promoted lipid oxidation in minced beef under } \\
\text { both high and low oxygen conditions. }\end{array}$ & Yi et al. (2015). \\
\hline Lactate enhancement on beef steaks is packaging-dependent. & Suman et al. (2010). \\
\hline Enhancing beef with lactate replenishes NADH via increased LDH activity, ultimately resulting in greater meat color stability. & Kim et al. (2006). \\
\hline
\end{tabular}

$\mathrm{PVC}=$ polyvinylchloride; $\mathrm{NADH}$ = reduced form of nicotinamide adenine dinucleotide; $\mathrm{LDH}$ = lactate dehydrogenase.

reliable data. Herein, we discussed a number of methods employed in color stability research and compare them with standard methods applicable to normal $\mathrm{pH}_{\mathrm{u}}$ beef muscles. It is important to note that these methods are inline with the Meat Color Measurement Guidelines issued by AMSA (2012): Mb quantification, MRA, and OCR.

There are two protocols for quantifying total $\mathrm{Mb}$ of fresh and cooked meat in AMSA's guidelines (AMSA, 2012): the first based on the isobestic spectrophotometric point and the second, by reducing all $\mathrm{Mb}$ forms to $\mathrm{DMb}$. Both strategies can be used for meat with high $\mathrm{pH}_{\mathrm{u}}$. However, the extraction of the pigment with neutral buffer (40 mM potassium phosphate, $\mathrm{pH} 6.8)$ is hampered in high $\mathrm{pH}$ meat, which results in incomplete total pigment extraction and, thus, in a pink color remaining in the centrifuge pellet after one extraction. In order to improve the pigment extraction, an acidic buffer adapted from Poel's Mb quantification method can be deployed (DeDuve, 1948; Hunt and Hedrick, 1977). The use of an acidic buffer (0.01 N, Hunt and Hedrick (1977), or $800 \mathrm{mM}$, McKeith et al. (2016), sodium acetate, pH 4.5) compensates for the native higher $\mathrm{pH}$ of the muscle, also observed in pre-rigor muscle (abdominal muscle from biopsy) as shown by DeDuve (1948). The repetition of the extraction step ensures the removal of $\mathrm{Mb}$ from the tissue, as followed by Hunt and Hedrick (1977) and McKeith et al. (2016).

The MRA method is based on the complete oxidation of $\mathrm{Mb}$ in sodium nitrite solution $10.3 \%$ for $20 \mathrm{~min}$ at $25{ }^{\circ} \mathrm{C}$ ) with subsequent $\mathrm{Mb}$ reduction under vacuum conditions at $20-30{ }^{\circ} \mathrm{C}$ for $2 \mathrm{~h}$. The estimation of the proportion of each $\mathrm{Mb}$ redox form is achieved by scanning samples with a Hunter Miniscan colorimeter with settings previously described that had been calibrated through the $\mathrm{O}_{2}$ impermeable film of a vacuum bag. Complete oxidation may be estimated by the ratio of specific wavelengths (572 nm/525 nm), being the proportion of each $\mathrm{Mb}$ redox form confirmed by the $630 \mathrm{~nm} / 580 \mathrm{~nm}$ ratio.

Another protocol for estimating the $\mathrm{MMb}$ redox form on the surface of the samples is based on the creation of reference standards for $100 \% \mathrm{MMb}$ and $\mathrm{DMb}$. Thus, the proportion of surface $\mathrm{MMb}$ is obtained by dividing the difference between $\mathrm{MMb}$ for $100 \% \mathrm{DMb}$ and for samples by the difference between $\mathrm{MMb}$ for $100 \%$ $\mathrm{DMb}$ and $100 \% \mathrm{MMb}$. However, $\mathrm{Mb}$ does not oxidize completely in $\mathrm{pH}_{u}$ meat $>5.8$, and does not result in $100 \% \mathrm{MMb}$ samples prior to vacuum-reduction. There is no method in the literature for achieving total $\mathrm{Mb}$ oxidation. Therefore, the initial MMb formation is used by a number of authors, such as McKeith et al. (2016). The initial $\mathrm{MMb}$ formation represents the proportion of surface $\mathrm{MMb}$ formed after $\mathrm{Mb}$ oxidation in sodium nitrite solution.

Instead of forcing $\mathrm{Mb}$ oxidation/reduction, as seen in MRA analysis, OCR methodology is based on the assessment of the $\mathrm{Mb}$ oxygenation/deoxygenation stimulated. In OCR protocol, described by Madhavi and Carpenter (1993), muscle samples are air-oxygenated for $2 \mathrm{~h}$ at $2{ }^{\circ} \mathrm{C}$ before vacuum-packaging (reading 1) and subsequent incubation for $20-30 \mathrm{~min}$ at $25-$ $30{ }^{\circ} \mathrm{C}$ (reading 2). Two readings assess the surface $\mathrm{OMb}$ proportion in order to evaluate mitochondrial $\mathrm{O}_{2}$ consumption during thermal incubation.

McKeith et al. (2016) observed that performing OCR in high $\mathrm{pH}_{\mathrm{u}}$, beef dark-cutting samples had lower initial blooming (before incubation) than normal $\mathrm{pH}_{\mathrm{u}}$ samples, failing to achieve $100 \%$ of $\mathrm{OMb}$ on the surface 
of the muscle - as was also observed by Krzywicki (1979). Therefore, similar to the behavior of MRA in high $\mathrm{pH}_{\mathrm{u}}$ samples, the evaluation of the proportion of the deoxygenated $\mathrm{OMb}$ may not be reached. Therefore, the use of the proportion of OMb formed during the blooming step is an interesting alternative for comparing OCR between samples.

Calculating $\mathrm{MMb}, \mathrm{OMb}$, and $\mathrm{DMb}$ proportions on the beef surface has been conducted by Krzywick (1979). However, assessment of the $\mathrm{Mb}$ states in high $\mathrm{pH}_{\mathrm{u}}$ muscle is challenging when disabling a full conversion of these forms, further to this $\mathrm{pH}_{\mathrm{u}}$ range changing muscle structure and WHC. English et al. (2016) estimated DC beef pigments by their reflectance values and demonstrated that using the $\mathrm{K} / \mathrm{S}$ ratios at isobestic points were useful. K/S improves pigment proportion quantification by making data more linear accounting for absorptive $(\mathrm{K})$ and scattering $(\mathrm{S})$ color properties; and its formula is $(1-R) 2 /(2 R)$, where $R$ is the reflectance obtained using a spectrophotometer (AMSA, 2012).

Although Ramanathan et al. (2010) have not worked with high $\mathrm{pH}_{\mathrm{u}^{\prime}}$ the authors showed that lactateenhancement in beef had changed the overall percentage reflectance. Nonetheless, $525 \mathrm{~nm}$ remained the isobestic point for $\mathrm{MMb}, \mathrm{OMb}$, and $\mathrm{DMb}$, while 572, 610, and $473 \mathrm{~nm}$ also remained isobestic for $\mathrm{MMb}, \mathrm{OMb}$, and $\mathrm{DMb}$, respectively. Therefore, these wavelengths are still useful for calculating surface pigment in high $\mathrm{pH}_{\mathrm{u}}$ beef using the following formulae: K/S $572 \div \mathrm{K} / \mathrm{S} 525$ $(\mathrm{MMb}), \mathrm{K} / \mathrm{S} 610 \div \mathrm{K} / \mathrm{S} 525(\mathrm{OMb})$, and $\mathrm{K} / \mathrm{S} 473 \div \mathrm{K} / \mathrm{S}$ 525 (DMb) (AMSA, 2012).

\section{Novelties in meat color studies of dark-cutting beef}

Molecular profiling techniques including metabolomic and proteomic, have been increasingly applied as targeted or non-targeted approaches to exploring biochemical changes in postmortem muscle and its influence on meat quality characteristics ( $\mathrm{Ma}$ et al., 2020). Mass spectrometry-based metabolomic and proteomic studies have been carried out to evaluate modifications in the metabolite and protein profile as proteins and metabolites are directly involved in molecular mechanisms related to color stability, lipid oxidation, WHC and tenderness in fresh meats (Kim et al., 2016; Li et al., 2018; Ma et al., 2017; Subbaraj et al., 2016).

On the subject of meat color, a proteomic study indicated that the sarcoplasmic proteome of color-stable longissimus lumborum beef muscle has higher levels of soluble antioxidant proteins (thioredoxin, peroxiredoxin-2, and peptide methionine sulfoxide reductase) and chaperones (heat-shock protein-27 $\mathrm{kDa}$ ) compared to the color-labile psoas major muscle (Joseph et al., 2012). In turn, Mato et al. (2019) assessed phosphoproteomic differences between dark-cutting and normal beef in response to pre-slaughter stress. These authors found that protein phosphorylation levels were three times higher in dark-cutting beef compared to normal beef. This effect was mainly observed in proteins with biological functions related to structural-contractile properties, actin polymerization, stress response, metabolism and electron transport chain.

As postmortem glycolysis and $\mathrm{pH}$ decline in muscle are associated with protein phosphorylation, a previous gel-based phosphoproteomic study hypothesized that phosphorylation modifies the $\mathrm{Mb}$ structure and its susceptibility to oxidation, thereby influencing meat color stability (Li et al., 2018). This study identified that the phosphorylation of color stability-related proteins regulates the activity of glycolytic enzymes, thus influencing meat discoloration.

In metabolomic studies, Ma et al. (2017) stated that metabolic pathways influencing both color and lipid oxidative stability in beef are dependent on the muscle type as well as the postmortem aging period. In fact, psoas major muscle was more susceptible to discoloration, lower free radical scavenging activity, higher nonheme iron content and lipid oxidation compared to semimembranosus and longissimus lumborum muscles, which were more stable. These authors reported that metabolites such as the NAD/NADH ratio, acyl carnitines, free amino acids, nucleotides, nucleosides, and glucuronides play an important role in the oxidative stabilization of beef muscles. These metabolites can be potential biomarkers for further validation studies.

To identify differentially abundant metabolites related to color stability from longissimus lumborum and psoas major muscle, a gas chromatographymass spectrometry (GC-MS) based non-targeted metabolomic approach was used by Abraham et al. (2017). The Longissimus lumborum muscle had higher levels of pyruvic acid, glucose 6-phosphate, fructose and citric acid compared to psoas major muscle. Additionally, key regulatory metabolites can increase MRA and mitochondrial activity. The malonic acid levels were higher in psoas major muscle when compared to the values found for longissimus lumborum. In fact, malonic acid is a complex II inhibitor recognized by promoting NADH oxidation, thus negatively affecting meat color (Abraham et al., 2017; Ramanathan et al., 2019).

In loins obtained from lamb carcasses and exposed to different storage conditions and display times, the metabolite profile was studied by a hydrophilic interaction liquid chromatography-mass spectrometry (HILIC-MS)-based metabolomic approach. The study identified metabolites including malic acid, NADH, and guanosine levels as being significantly higher in colorstable samples than in color-labile samples during aging (Subbaraj et al., 2016).

Moreover, as regards the differences in MRA and OCR, the influence of sarcoplasmic proteome and metabolome on the differential color stability of beef 
has been recently reported (Ramanathan et al., 2019; Mancini et al., 2018). These results indicated that muscle-specific differences in mitochondrial activity may partially contribute to variations in the color stability of longissimus lumborum and psoas major beef muscles.

\section{Final Remarks}

Dark-cutting beef has been cataloged as a multifactorial phenomenon dependent on ante and postmortem factors. Although not the exclusive factor, high $\mathrm{pH}_{\mathrm{u}}$ was the major influencing element to produce dark-cuts and their color stability, even though there was, at the time, no definitive cut-off $\mathrm{pH}$ for determining a carcass as high $\mathrm{pH}_{\mathrm{u}}$.

Animal genotype was observed as being one factor among several others that affect $\mathrm{pHu}$ drop and beef color color stability. However, there was little information available regarding an important breed in Brazilian herds: Nellore bulls and their crossbreeds.

The significant color stability found in the muscles with high $\mathrm{pHu}$ was outshone by the darker appearance which, closely associated with the increased mitochondrial OCR, reduces beef marketability. Postslaughter interventions, such as improvements in the use of organic acid salts through multi-needle injection followed by HiOx MAP either limited the oxidation of $\mathrm{Fe}^{2+}-\mathrm{Mb}$ or promoted reductions in $\mathrm{MMb}$.

Future studies should focus on the use of accurate techniques to quantify tissue OCR and MRA and their relationships to color stability of fresh dark-cutting meat, such as the -omics techniques, especially in Nellore bulls in order to substantiate the effect of animal phenotype on beef color.

\section{Acknowledgments}

This review was supported by the São Paulo Research Foundation (FAPESP), Thematic Project 17/26667-2 and Post-Doctoral Fellowship 19/18346-7.

\section{Authors' Contributions}

Conceptualization: Ribeiro, C.C.S.; Venturini, A.C. Data acquisition: Ribeiro, C.C.S.; Venturini, A.C. Data analysis: Contreras-Castillo, C.J.; Venturini, A.C. Design of methodology: Ribeiro, C.C.S.; ContrerasCastillo, C.J. Writing and editing: Ribeiro, C.C.S.; Contreras-Castillo, C.J.; Venturini, A.C.; SantosDonado, P.R.

\section{References}

Abraham, A.; Dillwith, J.W.; Mafi, G.G.; Van Overbeke, D.L.; Ramanathan, R. 2017. Metabolite profile differences between beef longissimus and psoas muscles during display. Meat and Muscle Biology 1: 18-26.
Abril, M.; Campo, M.M.; Önenç, A.; Sañudo, C.; Albert1, P.; Negueruela, A.I. 2001. Beef colour evolution as a function of ultimate pH. Meat Science 58: 69-78.

American Meat Science Association - International [AMSA]. 2012. Meat color measurement guidelines. AMSA, Champaign, IL, USA.

Apaoblaza, A.; Gerrard, S.D.; Matarneh, S.K.; Wicks, J.C.; Kirkpatrick, L.; England, E.M.; Scheffler, T.L.; Duckett, S.K.; Shia, H.; Silva, S.L.; Grant, A.L.; Gerrard, D.E. 2020. Muscle from grass- and grain-fed cattle differs energetically. Meat Science 161: 107996.

Arihara, K.; Cassens, R.G.; Greaser, M.L.; Luchansky, J.B.; Mozdziak, P.E. 1995. Localization of metmyoglobin-reducing enzyme (NADH-cytochrome b5 reductase) system components in bovine skeletal muscle. Meat Science 39: 205-213.

Ashmore, C.R.; Parker, W.; Doerr, L. 1972. Respiration of mitochondria isolated from dark-cutting beef: postmortem changes. Journal of Animal Science 34: 46-48.

Associação Brasileira das Indústrias Exportadoras de Carnes [ABIEC]. 2019. Beef Report: Brazilian Livestock Profile. ABIEC, São Paulo, SP, Brazil. Available at: http://www.brazilianbeef. org.br/download/sumarioingles2019.pdf [Accessed May 19, 2020]

Bechtold, E.; Suman, S.; Mohanty, S.; Mazumder, S.; Krishnan, S.; Nerimetla, R. 2019. Species-specificity in metmyoglobin reduction. Journal of Animal Science 97: 83-84.

Beef Cattle Research Council [BCRC]. 2018. National Beef Quality Audit - 2016/17 Plant Carcass Audit Results. [Medium]. BCRC, Calgary, Canada. Available at: http://www.beefresearch.ca/ files/pdf/NBQA-Carcass-Audit-Mar-27-2018-F.pdf [Accessed May 20, 2020]

Bekhit, A.E.D.; Faustman, C. 2005. Metmyoglobin reducing activity. Meat Science 71: 407-439.

Belskie, K.M.; Van Buiten, C.B.; Ramanathan, R.; Mancini, R.A. 2015. Reverse electron transport effects on NADH formation and metmyoglobin reduction. Meat Science 105: 89-92.

Bendall, J.R.; Taylor, A.A. 1972. Consumption of oxygen by the muscles of beef animals and related species. II. Consumption of oxygen by post-rigor muscle. Journal of the Science of Food and Agriculture 23: 707-719.

Bjelanovic, M.; Egelandsdal, B.; Phung, V. T.; Langsrud, Sørheim, O.; Hunt, M.; Slinde, E. 2016. Effects of metabolic substrates on myoglobin redox forms in packaged ground beef. Food Packaging and Shelf Life 8: 24-32.

Bomzon, A. 2011. Pain and stress in cattle: a personal perspective. Israel Journal of Veterinary Medicine 66: 12-20.

Bray, A.R.; Graafhuis, A.E.; Chrystall, B.B. 1989. The cumulative effect of nutritional, shearing and pre-slaughter washing stresses on the quality of lamb meat. Meat Science 25: 59-67.

Canto, A.C.V.C.S.; Costa-Lima, B.R.C.; Monteiro, M.L.G.; Viana, F.M.; Silva, T.J.P.; Suman, S.P.; Conte-Junior, C.A. 2016. Color attributes and oxidative stability of longissimus lumborum and psoas major muscles from Nellore bulls. Meat Science 121: 19-26.

Chmiel, M.; Slowinski, M.; Dasiewicz, K.; Florowski, T. 2012. Application of a computer vision system to classify beef as normal or dark, firm, and dry. Journal of Animal Science 90: 4126-4130. 
Choi, Y.M.; Kim, B.C. 2009. Muscle fiber characteristics, myofibrillar protein isoforms, and meat quality. Livestock Science 122: 105-118.

Coitzee, J.F.; Lubbers, B.V.; Toerber, S.E.; Gehring, R.; Thomson, D.U.; White, B.J.; Apley, M.D. 2008. Plasma concentration of substance $\mathrm{P}$ and cortisol in beef calves after castration and simulated castration. American Journal of Veterinary Research 69: $751-752$.

Contreras-Castillo, C.J.; Lomiwes, D.; Wu, G.; Frost, D.; Farouk, M.M. 2016. The effect of electrical stimulation on post mortem myofibrillar protein degradation and small heat shock protein kinetics in bull beef. Meat Science 113: 65-72.

Cruzen, S.M.; Kim, Y.H.B.; Lonergan, S.M.; Grubbs, J.K.; Fritchen, A.N.; Huff-Lonergan, E. 2015. Effect of early postmortem enhancement of calcium lactate/phosphate on quality attributes of beef round muscles under different packaging systems. Meat Science 101: 63-72.

Daniels, J.A.; Krishnamurthi, R.; Rizvi, S.S.H. 1985. A review of effects of carbon dioxide on microbial growth and food quality. Journal of Food Protection 48: 532-537.

DeDuve, C. 1948. A spectrophotometric method for the simultaneous determination of myoglobin and hemoglobin in extracts of human muscle. Acta Chemica Scandinavica 2: 264289.

Denzer, M.; Mowery, C.; Comstock, H.; Maheswarappa, N.B.; Mafi, G.G.; VanOverebeke, D.L.; Ramanathan, R. 2020. Characterization of the cofactors involved in nonenzymatic metmyoglobin/methemoglobin reduction in vitro. Meat and Muscle Biology 4: 1-10.

DeVol, D.L.; Vanderwert, W.; Bechtel, P.J.; McKeith, F.K. 1985. Comparison of $\mathrm{M}$. longissimus dorsi pigment concentration from implanted and control Angus and Limousin bulls and steers. Meat Science 14: 165-173.

Dunne, P.G.; Monahan, F.J.; Moloney, A.P. 2011. Current perspectives on the darker beef often reported from extensivelymanaged cattle: does physical activity play a significant role? Livestock Science 142: 1-22, 2011.

Dunne, P.G.; O'Mara, F.P.; Monahan, F.J.; French, P.; Moloney, A.P. 2005. Colour of muscle from 18-month-old steers given longterm daily exercise. Meat Science 71: 219-229.

Echevarne, C.; Renerre, M.; Labas, R. 1990. Metmyoglobin reductase activity in bovine muscles. Meat Science 27: 161-172.

England, E.M.; Matarneh, S.K.; Oliver, E.M.; Apaoblaza, A.; Scheffler, T.L.; Shi, H.; Gerrard, D.E. 2016. Excess glycogen does not resolve high ultimate $\mathrm{pH}$ of oxidative muscle. Meat Science 114: 95-102.

England, E.M.; Matarneh, S.K.; Scheffler, T.L.; Wachet, C.; Gerrard, D.E. 2014. $\mathrm{pH}$ inactivation of phosphofructokinase arrests postmortem glycolysis. Meat Science 98: 850-857.

English, A.R.; Wills, K.M.; Harsh, B.N.; Mafi, G.G.; Vanoverbeke, D.L.; Ramanathan, R. 2016. Effects of aging on the fundamental color chemistry of dark-cutting beef. Journal of Animal Science 94: 4040-4048.

Erikson, U.; Shabani, F.; Beli, E.; Muji, S.; Rexhepi, A. 2018. The impacts of perimortem stress and gutting on quality index and colour of rainbow trout (Oncorhynchus mykiss) during ice storage: a commercial case study. European Food Research and Technology 244: 197-206.
Faustman, C.; Cassens, R.G.; 1990. The biochemical basis for discoloration in fresh meat: a review. Journal of Muscle Foods 1: 217-43.

Faustman, C.; Sun, Q.; Mancini, R.; Suman, S.P. 2010. Myoglobin and lipid oxidation interactions: mechanistic bases and control. Meat Science 86: 86-94.

Fink, J.; Schoenfeld, B.J.; Nakazato, K. 2018. The role of hormones in muscle hypertrophy. Physician and Sportsmedicine 46: 129-134.

Gagaoua, M.; Monteils, V.; Couvreur, S.; Picard, B. 2017. Identification of biomarkers associated with the rearing practices, carcass characteristics, and beef quality: an integrative approach. Journal of Agricultural and Food Chemistry 65: 8264-8278.

George, P.; Stratmann, C. J. 1952. The oxidation of myoglobin to metmyoglobin by oxygen. I. The Biochemical Journal 51: 103-108.

Grabež, V.; Kathri, M.; Phung, V.; Moe, K.M.; Slinde, E.; Skaugen, M.; Saarem, K.; Egelandsdal, B. 2015. Protein expression and oxygen consumption rate of early postmortem mitochondria relate to meat tenderness. Journal of Animal Science 93: 1967-1979.

Grandin, T. 2010. Auditing animal welfare at slaughter plants. Meat Science 86: 56-65.

Grandin, T. 2019. Slaughter plants: behavior and welfare assessment. p. 153-162. In: Choe, J.C., ed. Encyclopedia of animal behavior. 2ed. Academic Press, San Diego, CA, USA.

Holdstock, J.; Aalhus, J.L.; Uttaro, B.A.; López-Campos, O.; Larsen, I.L.; Bruce H.L. 2014. The impact of ultimate $\mathrm{pH}$ on muscle characteristics and sensory attributes of the longissimus thoracis within the dark cutting (Canada B4) beef carcass grade. Meat Science 98: 842-849.

Holman, B.W.B.; Kerry, J.P.; Hopkins, D.L. 2018. Meat packaging solutions to current industry challenges: a review. Meat Science 144: 159-168.

Hughes, J.; Clarke, F.; Li, Y.; Purslow, P.; Warner, R. 2019. Differences in light scattering between pale and dark beef longissimus thoracis muscles are primarily caused by differences in the myofilament lattice, myofibril and muscle fibre vtransverse spacings. Meat Science 149: 96-106.

Hughes, J.M.; Kearney, G.; Warner, R.D. 2014a. Improving beef meat colour scores at carcass grading. Animal Production Science 54: 422-429.

Hughes, J.M.; Oiseth, S.K.; Purslow, P.P.; Warner, R.D. 2014 b. A structural approach to understanding the interactions between colour, water-holding capacity and tenderness. Meat Science 98: 520-532.

Hunt, M.C.; Hedrick, H.B. 1977. Chemical, physical and sensory characteristics of bovine muscle from four quality groups. Journal of Food Science 42: 716-720.

Instituto Brasileiro de Geografia e Estatística [IBGE]. 2020. IBGE Indicators: Livestock Production Statistics - OctDec 2019 = Indicadores IBGE: Estatística da Produção Pecuária - Out-Dez 2019. IBGE, Rio de Janeiro, RJ, Brazil. Available at: https://biblioteca.ibge.gov.br/visualizacao/ periodicos/2380/epp_2019_4tri.pdf [Accessed May 19, 2020] (in Portuguese). 
Instituto Brasileiro de Geografia e Estatística [IBGE]. 2019. = IBGE Indicators: Livestock Production Statistics - Apr-Jun 2019 = Indicadores IBGE: Estatística da Produção Pecuária - Abr-Jun 2019. IBGE, Rio de Janeiro, RJ, Brazil. Available at: https://biblioteca.ibge.gov.br/visualizacao/periodicos/2380/ epp_2019_2tri.pdf [Accessed May 19, 2020] (in Portuguese).

Jayasingh, P.; Cornforth, D.P.; Brennand, C.P.; Carpenter, C.E.; Whittier, D.R. 2002. Sensory evaluation of ground beef stored in high-oxygen modified atmosphere packaging. Journal of Food Science 67: 5-8.

Jerez-Timaure, N.; Gallo, C.; Ramírez-Reveco, A.; Greif, G.; Strobel, P.; Pedro, A.V.F.; Morera, F.J. 2019. Early differential gene expression in beef Longissimus thoracis muscles from carcasses with normal $(<5.8)$ and high $(>5.9)$ ultimate $\mathrm{pH}$. Meat Science 153: 117-125.

Johnson, B.J.; Chung, K.Y. 2007. Alterations in the physiology of growth of cattle with growth-enhancing compounds. Veterinary Clinics of North America - Food Animal Practice 23: 321-332.

Joseph, P.; Suman, S.P.; Rentfrow, G.; Li, S.; Beach, C.M. 2012. Proteomics of muscle specific beef color stability. Journal of Agricultural Food Chemistry 60: 3196-3203.

Kandeepan, G.; Anjaneyulu, A.S.R.; Rao, V.K.; Pal, U.K.; Mondal, P.K.; Das, C.K. 2009. Feeding regimens affecting meat quality characteristics. MESO 11: 241-249.

Kim, Y.H.; Hunt, M.C.; Mancini, R.A.; Seyfert, M.; Loughin, T.M.; Kropf, D.H.; Smith, J.S., 2006. Mechanism for lactatecolor stabilization in injection-enhanced beef. Journal of Agricultural Food Chemistry 54: 7856-7862.

Kim, Y.H.; Keeton, J.T.; Smith S.B.; Berghman, L.R.; Savell, J.W. 2009. Role of lactate dehydrogenase in metmyoglobin reduction and color stability of different bovine muscles. Meat Science 83: 376-382.

Kim, Y.H.B.; Kemp, R.; Samuelsson, L.M. 2016. Effects of dryaging on meat quality attributes and metabolite profiles of beef loins. Meat Science 111: 168-176.

King, D.A.; Schuehle P.C.E.; Randel, R.D.; Welsh, T.H.Jr.; Oliphint, R.A.; Baird, B.E.; Curley Jr., K.O.; Vann, R.C.; Hale, D.S.; Savell, J.W. 2006. Influence of animal temperament and stress responsiveness on the carcass quality and beef tenderness of feedlot cattle. Meat Science 74: 546556.

King, D.A.; Shackelford, S.D.; Kuehn, L.A.; Kemp, C.M., Rodriguez; A.B., Thallman, R.M.; Wheeler, T.L. 2010. Contribution of genetic influences to animal-to-animal variation in myoglobin content and beef lean color stability. Journal of Animal Science 88: 1160-1167.

Kirchofer, K.S.; Calkins, C.B.; Gwartney, B.L. 2002. Fiber-type composition of muscles of the beef chuck and round. Journal of Animal Science 80: 2872-2878.

Knock, R.C.; Seyfert, M.; Hunt, M.C.; Dikeman, M.E.; Mancini, R.A.; Unruh, J.A.; Higgins J.J.; Monderen, R.A. 2006. Effects of potassium lactate, sodium chloride, sodium tripolyphosphate, and sodium acetate on colour, colour stability, and oxidative properties of injection-enhanced beef rib steaks. Meat Science 74: 312-318.

Krzywicki, K. 1979. Assessment of relative content of myoglobin, oxymyoglobin and metmyoglobin at the surface of beef. Meat Science 3: 1-10.
Kuswandi, B.; Nurfawaidi, A. 2017. On-package dual sensors label based on $\mathrm{pH}$ indicators for real-time monitoring of beef freshness. Food Control 82: 91-100.

Lawrence, L.J.; Fowler, V.R.; Novakofski, J.E. 2012. Growth of Farm Animals. 3ed. CABI, Wallingford, UK.

Lawrence, T.E.; Dikeman, M.E.; Hunt, M.C.; Kastner, C.L.; Johnson, D.E. 2003. Effects of calcium salts on beef longissimus quality. Meat Science 64: 299-308.

Lawrie, R.A. 1958. Physiological stress in relation to dark-cutting beef. Journal of the Science of Food and Agriculture 9: 721-727.

Ledward, D.A. 1971. Metmyoglobin formation in beef muscles as influenced by water content and anatomical location. Journal of Food Science 61: 138-140.

Ledward, D.A. 1985. Post-slaughter influences on the formation of metmyoglobin in beef muscles. Meat Science 15: 149-171.

Li, M.; Li, Z.; Li, X.; Xin, J.; Wang, Y.; Li, G.; Wu, L.; Shen, Q. W.; Zhang, D. 2018. Comparative profiling of sarcoplasmic phosphoproteins in ovine muscle with different color stability. Food Chemistry 240: 104-111.

Li, P.; Wang, T.; Mao, Y.; Zhang, Y.; Niu, L.; Liang, R.; Zhu, L.; Luo, X. 2014. Effect of Ultimate $\mathrm{pH}$ on postmortem myofibrillar protein degradation and meat quality characteristics of Chinese yellow crossbreed cattle. The Scientific World Journal 2014: 1-8.

Lomiwes, D.; Farouk, M.M.; Frost, D.A.; Dobbie, P.M.; Young, O.A. 2013. Small heat shock proteins and toughness in intermediate pHu beef. Meat Science 95: 472-479.

Lomiwes, D.; Hurst, SM.; Dobbie, P.; Frost, DA.; Hurst, R.D.; Young, O.A.; Farouk, M.M. 2014. The protection of bovine skeletal myofibrils from proteolytic damage post mortem by small heat shock proteins. Meat Science 97: 548-557.

Lu, X.; Cornforth, D.P.; Carpenter, C.E.; Zhu, L.; Luo, X. 2020. Effect of oxygen concentration in modified atmosphere packaging on color changes of the M. longissimus thoraces et lumborum from dark cutting beef carcasses. Meat Science 161: 107999.

Ma, D.; Kim, Y.H.B.; Cooper, B.R.; Oh, J.H.; Chun, H.; Choe, J.; Schoonmaker, J.P.; Ajuwon, K.M.; Min, B. 2017. Metabolomics profiling to determine the effect of postmortem aging on color and lipid oxidative stabilities of different bovine muscles. Journal of Agricultural and Food Chemistry 65: 6708-6716.

Ma, D.; Yu, Q.; Hedrick, V.E.; Cooper, B.R.; Sobreira, T.J.P.; Oh, J.H.; Chun, H.; Kim, Y.H.B. 2020. Proteomic and metabolomic profiling reveals the involvement of apoptosis in meat quality characteristics of ovine $M$. longissimus from different callipyge genotypes. Meat Science 166: 108-140.

MacDougall, D.B. 1982. Changes in the colour and opacity of meat. Food Chemistry 9: 75-88.

Mach, N.; Bach, A.; Velarde, A.; Devant, M. 2008. Association between animal, transportation, slaughterhouse practices, and meat $\mathrm{pH}$ in beef. Meat Science 78: 232-238.

Madhavi, D.L.; Carpenter, C.E. 1993. Aging and processing affect color, metmyoglobin reductase and oxygen consumption of beef muscles. Journal of Food Science 58: 939-942.

Mancini, R.A.; Belskie, K.; Suman, S.P.; Ramanathan, R. 2018. Muscle-specific mitochondrial functionality and its influence on fresh beef color stability. Journal of Food Science 83: 2077-2082.

Mancini, R.A.; Hunt, M.C. 2005. Current research in meat color. Meat Science 71: 100-121. 
Mancini, R.A.; Ramanathan, R. 2014. Effects of postmortem storage time on color and mitochondria in beef. Meat Science 98: 65-70.

Mancini, R.A.; Seyfert, M.; Hunt, M.C. 2008. Effects of data expression, sample location, and oxygen partial pressure on initial nitric oxide metmyoglobin formation and metmyoglobinreducing-activity measurement in beef muscle. Meat Science 79: 244-251.

Mato, A.; Rodríguez-Vázquez, R.; López-Pedrouso, M.; Bravo, S.; Franco, D.; Zapata, C. 2019. The first evidence of global meat phosphoproteome changes in response to pre-slaughter stress. BMC Genomics 20: 1-15.

McGilchrist, P.; Alston, C.L.; Gardner, G.E.; Thomson, K.L.; Pethick, D.W. 2012. Beef carcasses with larger eye muscle areas, lower ossification scores and improved nutrition have a lower incidence of dark cutting. Meat Science 92: 474-480.

McKeith, R.O.; King, D.A.; Grayson, A.L.; Shackelford, S.D.; Gehring, K.B.; Savell, J.W.; Wheeler T.L. 2016. Mitochondrial abundance and efficiency contribute to lean color of dark cutting beef. Meat Science 116: 165-173.

McMillin, K.W. 2008. Where is MAP going? A review and future potential of modified atmosphere packaging for meat. Meat Science 80: 43-65.

Mlynek, K.; Janiuk, I.; Dzido, A. 2012. Effect of growth intensity of bulls on the microstructure of musculus longissimus lumborum and meat quality. Acta Veterinaria Brno 81: 127-131.

Møller, J.K.S.; Skibsted, L.H. 2006. Myoglobins: the link between discoloration and lipid oxidation in muscle and meat. Quimica Nova 29: 1270-1278.

Moore, M.C.; Gray, G.D.; Hale, D.S.; Kerth, C.R.; Griffin, D.B.; Savell, J.W.; Raines, C.R.; Belk, K.E.; Woerner, D.R.; Tatum, J.D.; Igo, J.L.; Van Overbeke, D.L.; Mafi, G.G.; Lawrence, T.E.; Delmore, R.J. Jr; Christensen, L.M.; Shackelford, S.D.; King, D.A.; Wheeler, T.L.; Meadows, L.R.; O'Connor, M.E. 2012. National Beef Quality Audit-2011: In-plant survey of targeted carcass characteristics related to quality, quantity, value, and marketing of fed steers and heifers. Journal of Animal Science 90: 5152-5160.

Mueller, L.F.; Balieiro, J.C.C.; Ferrinho, A.M.; Martins, T.S.; Corte, R.R.P.S.; Amorim, T.R.; Furlan, J.J.M.; Baldi, F.; Pereira, A.S.C. 2019. Gender status effect on carcass and meat quality traits of feedlot Angus $\times$ Nellore cattle. Journal of Animal Science 90: 1078-1089.

O'Keeffe, M.; Hood, D.E. 1980-81. Anoxic storage of fresh beef. 1. Nitrogen and carbon dioxide storage atmospheres. Meat Science 5: 27-39.

O'Keeffe, M.; Hood, D.E. 1982. Biochemical factors influencing metmyoglobin formation on beef from muscles of differing colour stability. Meat Science 7: 209-228.

O'Sullivan, M.G.; Le Floch, S.; Kerry, J.P. 2015. Resting of MAP (modified atmosphere packed) beef steaks prior to cooking and effects on consumer quality. Meat Science 101: 13-18.

Ouali, A.; Herrera-Mendez, C.H.; Coulis, G.; Becila, S.; Boudjellal, A.; Aubry, L.; Sentandreu, M.A. 2006. Revisiting the conversion of muscle into meat and the underlying mechanisms. Meat Science 74: 44-58.

Page, J.K.; Wulf, D.M.; Schwotzer, T.R. 2001. A survey of beef muscle color and pH. Journal of Animal Science 79: 678-687.
Park, B.Y.; Lee, J.M.; Hwang, I.H. 2007. Effect of postmortem metabolic rate on meat color. Asian-Australasian Journal of Animal Science 20: 598-604.

Patten, L.E.; Hodgen, J.M.; Stelzleni, A.M.; Calkins, C.R.; Johnson, D.D.; Gwartney, B.L. 2008. Chemical properties of cow and beef muscles: benchmarking the differences and similarities. Journal of Animal Science 86: 1904-1916.

Picard, B.; Gagaoua, M. 2020. Muscle fiber properties in cattle and their relationships with meat qualities: an overview. Journal of Agricultural and Food Chemistry 68: 6021-6039.

Ponnampalam, E.N.; Hopkins, D.L.; Bruce, H.; Li, D.; Baldi, G.; Bekhit, A.E.D. 2017. Causes and contributing factors to "dark cutting" meat: current trends and future directions; a review. Comprehensive Reviews in Food Science and Food Safety 16: 400-430.

Probst, J.K.; Hillmann, E.; Leiber, F.; Keuzer, M.; Neff, A.S. 2013. Influence of gentle touching applied few weeks before slaughter on avoidance distance and slaughter stress in finishing cattle. Applied Animal Behaviour Science 144: 14-21.

Pulford, D.J.; Vazquez, S.F.; Frost, D.F.; Fraser-Smith, E.; Dobbie, P.; Rosenvold, K. 2008. The intracellular distribution of small heat shock proteins in post-mortem beef is determined by ultimate pH. Meat Science 79: 623-630.

Ramanathan, R.; Mancini, R.A. 2018. Role of mitochondria in beef color: a review. Meat and Muscle Biology 2: 309-320.

Ramanathan, R.; Mancini, R.A.; Dady, G.A. 2011a. Effects of pyruvate, succinate, and lactate enhancement on beef longissimus raw color. Meat Science 88: 424-428.

Ramanathan, R.; Mancini, R.A.; Joseph, P.; Yin, S.; Tatiyaborworntham, N.; Petersson, K.H.; Sun, Q.; Konda, M.R. 2011b. Effects of lactate on ground lamb colour stability and mitochondria- mediated metmyoglobin reduction. Food Chemistry 126: 166-171.

Ramanathan, R.; Mancini, R.A.; Naveena, B.M.; Konda, M.K.R. 2010. Effects of lactate-enhancement on surface reflectance and absorbance properties of beef longissimus steaks. Meat Science 84: 219-226.

Ramanathan, R.; Nair, M.N.; Hunt, M.C.; Suman, S.P. 2019. Mitochondrial functionality and beef colour: a review of recent research. South African Journal of Animal Science 49: 9-19.

Ramanathan, R.; Mancini, R.A.; Joseph, P.; Suman, S.P. 2013. Bovine mitochondrial oxygen consumption effects on oxymyoglobin in the presence of lactate as a substrate for respiration. Meat Science 93: 893-897.

Ramanathan, R.; Mancini, R.A.; Suman, S.P.; Cantino, M.E. 2012. Effects of 4-hydroxy -2-nonenal on beef heart mitochondrial ultrastructure, oxygen consumption, and metmyoglobin reduction. Meat Science 90: 564-571.

Reddy, L.M.; Carpenter, C.E. 1991. Determination of metmyoglobin reductase activity in bovine skeletal muscles. Journal of Food Science 56: 1161-1164.

Renerre, M. 1990. Factors involved in the discoloration of beef meat. International Journal of Food Science and Technology 25: 613-630.

Rosa, A.; Fonseca, R.; Balieiro, J.C.; Poletid, M.D.; DomenechPéreze, K.; Farnetanib, B.; Elera, J. 2016. Incidence of DFD meat on Brazilian beef cuts. Meat Science 112: 132-136. 
Salim, A.P.A.A.; Suman, S.P.; Canto, A.C.V.C.S.; CostaLima, B.R.C.; Viana, F.M.; Monteiro, M.L.G.; Silva, T.J.P.; Conte-Junior, C.A. 2019. Muscle-specific color stability in fresh beef from grain-finished Bos indicus cattle. AsianAustralasian Journal of Animal Science 32: 1036-1043.

Sammel, L.M.; Hunt, M.C.; Kropf, D.H.; Hachmeister, K.A.; Johnson, D.E. 2002. Comparison of assays for metmyoglobin reducing ability in beef inside and outside semimembranosus muscle. Journal of Food Science 67: 978-984.

Santos, P.R.; Contreras-Castillo, C.J.; Venturini, A.C. 2016. Color stability of Bos indicus bull steaks in modified atmosphere packaging (MAP). Scientia Agropecuaria 7: 401 $-408$.

Scheffler, T.L.; Matarneh, S.K.; England, E.M.; Gerrard, D.E. 2015. Mitochondria influence postmortem metabolism and $\mathrm{pH}$ in an in vitro model. Meat Science 110: 118-125.

Seideman, S.C.; Cross, H.R.; Oltjen, R.R.; Schanbacher, B.D. 1982. Utilization of the intact male for red meat production: a review. Journal of Animal Science 55: 826-840.

Seyfert, M.; Mancini, R.A.; Hunt, M.C.; Tang, J.; Faustman, C.; Garcia, M. 2006. Color stability, reducing activity, and cytochrome c oxidase activity of five bovine muscles. Journal of Agricultural and Food Chemistry 54: 8919-8925.

Shukla, V.; Kandeepan, G.; Vishnuraj, M.R. 2015. Development of on-package indicator sensor for real-time monitoring of buffalo meat quality during refrigeration storage. Food Analytical Methods 8: 1591-1597.

Stackhouse, R.J.; Apple, J.K.; Yancey, J.W.S.; Keys, C.A.; Johnson, T.M.; Mehall, L.N. 2016. Postrigor citric acid enhancement can alter cooked color but not fresh color of dark-cutting beef. Journal of Animal Science 94: 1738-1754.

Subbaraj, A.K.; Kim, Y.H.B.; Fraser, K.; Farouk, M.M. 2016. A hydrophilic interaction liquid chromatography-mass spectrometry (HILIC-MS) based metabolomics study on colour stability of ovine meat. Meat Science 117: 163-172.

Suman, S.P.; Hunt, M.C.; Nair, M.N.; Rentfrow, G. 2014. Improving beef color stability: practical strategies and underlying mechanisms. Meat Science 98: 490-504.

Suman, S.P.; Mancini, R.A.; Joseph, P.; Ramanathan, R.; Konda, M.K.R.; Dady, G.; Naveena, B.M.; López-López, I. 2010. Color-stabilizing effect of lactate on ground beef is packaging-dependent. Meat Science 84: 329-333.

Suman, S.P.; Mancini, R.A.; Ramanathan, R.; Konda, M.R. 2009. Effect of lactate-enhancement, modified atmosphere packaging, and muscle source on the internal cooked colour of beef steaks. Meat Science 81: 664-670.

Sun, X.D.; Holley, R.A. 2012. Antimicrobial and antioxidative strategies to reduce pathogens and extend the shelf life of fresh red meats. Comprehensive Reviews in Food Science and Food Safety 11: 340-354.

Tang, J.; Faustman, C.; Hoagland, T.A.; Mancini, R.A.; Seyfert, M.; Hunt, M.C. 2005. Postmortem oxygen consumption by mitochondria and its effects on myoglobin form and stability. Journal of Agricultural and Food Chemistry 53: 1223-1230.
Vaughn, M.A.; Lancaster, P.A.; Roden, K.C.; Sharman, E.D.; Krehbiel, C.R.; Horn, G.W.; Starkey, J.D. 2019. Effect of stocker management program on beef cattle skeletal muscle growth characteristics, satellite cell activity, and paracrine signaling impact on preadipocyte differentiation. Journal of Animal Science and Technology 61: 260-271.

Venturini, A.C., Faria, J.A.F., Olinda, R.A., Contreras-Castillo, C.J., 2014. Shelf life of fresh beef stored in master packages with carbon monoxide and high levels of carbon dioxide. Packaging Technology and Science 27: 29-35.

Viljoen, H.F.; De Kock, H.L.; Webb, E.C. 2002. Consumer acceptability of dark, firm and dry (DFD) and normal $\mathrm{pH}$ beef steaks. Meat Science 61: 181-185.

Voisinet, B.D., Grandin, T., O'Connor, S.F., Tatum, J.D., Deesing, M.J., 1997. Bos indicus-cross feedlot cattle with excitable temperaments have tougher meat and a higher incidence of borderline dark cutters. Meat Science 46: 367-377.

W glarz, A. 2010. Meat quality defined based on $\mathrm{pH}$ and colour depending on cattle category and slaughter season. Czech Journal of Animal Science 55: 548-556.

Wicks, J.; Beline, M.; Gomez, J.F.M.; Luzardo, S.; Silva, S.L.; Gerrard, D. 2019. Muscle energy metabolism, growth, and meat quality in beef cattle. Agriculture 9: 1-10.

Wills, K.M.; Mitacek, R.M.; Mafi, G.G.; Vanoverbeke, D.L.; Jaroni, D.; Jadeja, R.; Ramanathan, R. 2017. Improving the lean muscle color of dark-cutting beef by aging, antioxidantenhancement, and modified atmospheric packaging. Journal of Animal Science 95: 5378-5387.

Wu, G; Farouk, M.M.; Clerens, S.; Rosenvold, K. 2014. Effect of beef ultimate $\mathrm{pH}$ and large structural protein changes with aging on meat tenderness. Meat Science 98: 637-645.

Wu, S.; Luo, X.; Yang, X.; Hopkins, D.L.; Mao, Y.; Zhang, Y. 2020. Understanding the development of color and color stability of dark cutting beef based on mitochondrial proteomics. Meat Science 163: 108046.

Wulf, D.M.; Emnett, R.S.; Leheska, J.M.; Moeller, S.J. 2002. Relationships among glycolytic potential, dark cutting (dark, firm, and dryl beef, and cooked beef palatability. Journal of Animal Science 80: 1895-1903.

Yi, G.; Grabež, V.; Bjelanovic, M.; Slinde, E.; Olsen, K.; Langsrud, O.; Phung, V.T.; Haug, A.; Oostindjer, M.; Egelandsdal, B. 2015. Lipid oxidation in minced beef meat with added Krebs cycle substrates to stabilise colour. Food Chemistry 187: 563-571.

Zerouala, A.C.; Stickland, N.C. 1991. Cattle at risk for darkcutting beef have a higher proportion of oxidative muscle fibres. Meat Science 29: 263-270.

Zhai, C.; Peckham, K.; Belk, K.E.; Ramanathan, R.; Nair, M.N. 2019. Carbon chain length of lipid oxidation products influence lactate dehydrogenase and NADH-dependent metmyoglobin reductase activity. Journal of Agricultural and Food Chemistry 67: 13327-13332.

Zhang, Y.; Qin, L.; Mao, Y.; Hopkins, D.L.; Han, G.; Zhu, L.; Luo, X. 2018. Carbon monoxide packaging shows the same color improvement for dark cutting beef as high oxygen packaging. Meat Science 137: 153-159. 